\title{
Piyasa Koşullarında Kentsel Sit Kararının Taşınmaz Değeri Üzerindeki Etkileri: Talas (Kayseri) Örneği
}

\section{The Effects of Conservation Registration Status on Real Estate Market Values on Talas (Kayseri) Case}

\section{Ceyhan Yücel, ${ }^{1}$ (iD Samet Sakal²}

${ }^{1}$ Erciyes Üniversitesi Mimarlık Fakültesi, Şehir ve Bölge Planlama Bölümü, Kayseri

${ }^{2}$ Erciyes Üniversitesi Fen Bilimleri Enstitüsü, Şehir ve Bölge Planlama Anabilim Dalı, Yüksek Lisans Programı, Kayseri

\section{ÖZ}

Bir kentin mirası otantik nitelikleri ile kent kültürü ve kimliğinin vazgeçilmez unsurlarıdır. Koruma altına alınmış mirasın toplumsal ve kültürel değerlerinin, ölçmeye ya da tartışmaya yer bırakmadan kabul edilmesi beklenir. Diğer yandan, toplumun ortak kültürünün öğeleri olan bu değerler, özel mülkiyet haklarından ötürü taşınmaz piyasasına konu olduklarından, kentsel gelişme dinamiklerinin ve imar koşullarının da doğrudan etkisi altında kalmaktadırlar. Bu açıdan toplumsal değer ve ekonomik değer arasındaki ilişki kentsel koruma eyleminin amacına ulaşmasında önemli bir parametre haline gelmektedir. Korumada başarılı sonuçlara ulaşabilmek için mirasın toplumsal ve kültürel değeri üzerinde tüm aktörler arasında bir konsensüs zorunludur. Ancak, Ülkemizde gözlenen deneyimler dikkate alındığında koruma statüsü ve kararlarının tarihi miras açısından ekonomik anlamda olumsuz bir algı yarattığı görülmektedir. Bu çalışmada Talas (Kayseri) kentsel sit alanının içinde ve dışında yer alan taşınmazların 2012-2019 yılları arasında gösterdiği ekonomik değer değişiminin karşılaştırılması amaçlamaktadır. Sit alanı içinde bulunan ama üzerinde tescil kaydı bulunmayan taşınmazlar ile kentsel sit alanı dışında bulunan ve son dönemde hızlı kentleşme gösteren alanlarda bulunan taşınmazların değerleri enflasyon, döviz ve hedonik konut fiyat endeksi oranları açısından hesaplanmış ve karşılaştırılmıştır. Makalede Talas'ta kentleşme sürecinde yaşanan hızıı rant dönüşümü ve kentsel sit alanında taşınmaz değerlerindeki gözlenen değişim, sermaye piyasası koşullarında gerçekleşmiş rakamları ile tartışılmıştır.

Anahtar sözcükler: Gayrimenkul değerleme; gayrimenkul piyasası; kentsel sit; koruma.

\section{ABSTRACT}

The heritage of a city is the essential element of urban culture and identity with their authentic qualities. The social and cultural values of the registered heritage are expected to be agreed on without any consideration or argumentation. On the other hand, these values are under the direct influence of urban development and construction sector because they, at the same time, are the economic properties together with ownership rights. In this respect, the relationship between social value and economic value becomes an important parameter in achieving the goal of urban conservation action. In order to obtain successful results in conservation a consensus on the social and cultural value of the heritage is mandatory among all actors. However, considering our experiences it is seen that the heritage registration and conservation status create a negative perception for historic buildings or areas in economic manner. This paper aims to compare the economic value changes of the real estates that are positioned inside and outside of the Talas (Kayseri) urban conservation area between 2012 and 2019. The plots that are not registered as heritage in urban conservation area and the plots take place in rapidly urbanised parts of Talas outside of the conservation area are valuated and compared according to inflation, euro and hedonic hosing price index ratios. The paper argues the rapid rent transformation experienced in urbanization process in Talas and changes in the values of real estates in urban conservation area by using the official figures realised in capital market conditions.

Keywords: Real estate valuation; real estate market; urban conservation area; conservation.
Geliş tarihi: 21.04.2020 Kabul tarihi: 03.01.2021

Online yayımlanma tarihi: II.02.202 I

İletişim: Ceyhan Yücel

e-posta: ceyhanyucel@erciyes.edu.tr
TMMOB

Şehir Plancıları Odası 


\section{Giriş}

Koruma ve değişim olgularının kentsel mekandaki yansımalarının belirleyen öncelikli etkenlerin başında ekonomik koşullar gelmektedir. Koruma eyleminin durağan doğası karşısında, özellikle dinamik kentlerde yaşanan devinim, değişime yönelik eylemlerin mekân öğeleri üzerinde daha etkin olmasına yol açmaktadır. Bu noktada, mirasın toplumsal ve kültürel değeri ile ekonomik değer arasındaki denge, piyasa koşulları doğrultusunda kurulmaktadır. Bu açıdan Ülkemiz koşullarında, yere ilişkin spesifik koşullara bağlı olarak, ekonomik bağlamda koruma süreçlerine ilişkin olumsuz bir algının var olduğu söylenebilir.

Resmi olarak tescillenerek miras statüsü kazanmış taşınmazların değerlerinde yaşanan değişimler konusunda başlıca iki parametre ile ekonomik etki analizler üretildiği dile getirilmektedir. Bu parametrelerin ilki, sit, tescil kararı öncesi ve sonrası yapı ve emlak değerindeki değişimin saptanması ve alanda veya yakınında benzer tescilsiz yapı değeri değişimi ile karşılaştırılması; diğeri sit alanı içinde ve dışında bulunan, tescilli ve tescilsiz yapıların satış/el değiştirme kabiliyetlerinin karşılaştırılmasıdır. Ancak bu literatürün yoğun miktarda $A B D$ ve sınırlı sayıda Avrupa verileri üzerine olduğu görülmektedir. Ülkemizde ise korumanın ekonomik analizi konusunda oldukça sınırlı sayıda çalışma bulunmakta, doğrudan sit alanı ilanı ve tescil kararının yarattı̆̆ı ekonomik etkiler konusunda üretilmiş verilere pek ulaşılamamaktadır (Ökten, 20I2). Yine de yakın dönemde özellikle değerleme yöntemleri esas alınarak yapılan çalışmalar literatürde yer almaya başlamıştır (bkz. Yalpır, 2007 ve Aliefendioğlu, 20I I).

Ülkemizde sermaye piyasası konusunda son yıllarda yapılan düzenlemeler ile taşınmaz değerleme konusunda piyasa dengesi ve rekabet koşullarının düzenlenmesi ve spekülatif ya da yanlış uygulamaların önlenmesi adına önemli adımlar atılmıştır. Bu koşullar içinde, kentsel sit alanlarında yer alan taşınmazların ekonomik değerlerinin daha nesnel ölçütlerle belirlenmesi yönünde çalışmaların gerçekleştirilmesi kısa vadede daha olanaklı hale gelecektir.

Kültürel miras kavramı, koruma ve ekonomi alanlarında farklı şekilde ele alınmaktadır. Koruma disiplini, kültürel mirası yenilenemez bir kamusal kaynak olarak kabul ederken ekonomi disiplini kültürel mirası yenilenebilir bir ekonomik kaynak olarak ele almaktadır. Koruma uzmanları kültürel mirasın kültürel, sosyal ve kamusal değerlerine yoğunlaşırken; ekonomistler bireysel faydayı göz önüne alan değişim/ikame ve kullanım değerine odaklanmaktadır (Noonan ve Krupka (2008), Eichengreen (1997) ve Klamer ve Zuidhof'dan (1998) aktaran Ökten, 2012). Her iki disiplinin kendi faaliyet alanlarına göre uyguladığı değerlendirme eylemlerinde; ekonomik verilerin, kültürel mirasın duygusal, estetik, nadirlik gibi rakamlarla ifade edilemeyen ancak yapının bedelini belirleyen temel ölçütleri ifade edememesi, piyasa koşullarında bedel belirlemeye yönelik ekonomik modellerin uygulanması önündeki en önemli engel olmaktadır (Ost'dan (20I0) aktaran Ökten, 20I2).

Koruma kararlarının, daha spesifik olarak tescil kararlarının, miras üzerinde yarattığı etkiler konusunda (ağırlıklı olarak taşınmazların sahip oldukları niteliklerin de etkisini ölçmeyi hedefleyen hedonik fiyat ya da hedonik regresyon modelleri kullanılarak) yapılan çalışmalarda, genelde mirasın ekonomik değeri üzerinde artış sağladığı yönünde sonuçlar elde edilmiştir (Bu konuda yapılmış başlıca araştırmalar için bkz. Asabere, Huffman ve Mehdian (1994), Cebula (2009), Noonan ve Krupka (20II), Thompson, Rosenbaum ve Schmitz (20II), Licciardi ve Amirtahmasebi (20I2), Heintzelman ve Altieri (20I3), Noonan (20l3), Lazrak, Nijkamp, Rietveld ve Rouwendal (20|4)).

Koruma planlamasının başarısının açık bir ölçütü olarak görünen taşınmaz değerindeki artış, tescillenmenin kâr getirici kullanıcıları çekerek koruma alanındaki taşınmazların değerinin artacağı varsayımı ile tescil işlemi ve değer arasında kurulan bağlantı ile ifade edilmektedir. Miras eserleri, deneyimleri ve yerlerinin değeri, ekonomik sistemdeki diğer mal ve hizmetlerin değerinden açıkça daha karmaşıktır. Bu değerlerin sadece belirlenmesi değil nicelik değerinin hesaplanması da çok daha zordur. Bunun için ekonomik sistem içinde değer, pazarlar, üretim ve tüketim gibi ekonominin temel kavramlarından elde edilen bir dizi önemli açıklayıcı vardır. Mirasın değeri, içinde talebin doğrudan tüketim ile eşitlenemeyeceği diğer pek çok mal ve hizmetinkinden daha karmaşıktır (Ashworth, 2002).

Tescillemenin mevcut yatırım çevresini daha iyi ya da daha kötü şekilde aniden değiştiren beklenmedik ve dişsal olarak yüklenmiş bir koşul olduğunu belirten Lichfield, bu işlemin uzun vadede korunan alanın bütün olarak değerinde artışa yol açsa da bireysel mallarda ve arsa değerinde başta bir düşüşe yol açtığını dile getirmektedir (Lichfield (1988) ve Lichfield (1997)'den aktaran Ashworth, 2002). Diğer yandan, miras alanlarında koruma planlamaları kapsamında gerçekleştirilen canlandırma projeleri, özellikle konut alanlarında, alandaki değer artışına bağlı olarak daha az varlıklı kesimlerin ya da özgün kullanıcıların alandan ayrılmalarına sebep olabilmekte, fıyat artışına bağı olarak soylulaştırma baskılarının artmasına ve alanda alt-gelir gruplarının terkine sebep olabilmektedir (Leichenko, Coulson ve Listokin, 200I).

Yukarıda bahsedilen araştırmalarda, miras olarak tescilleme işlemlerinin ve sonrasında uygulanan koruma amaçlı planlamaların, ağırlıkla $A B D$ ve büyük Avrupa şehirlerinde, yapısal miras ve koruma alanlarında artışa yol açtığı; hatta ABD'de yerel düzeyde ya da ulusal ölçekte ayrı ayrı yapılan tescil işlemi sonrasında ulusal miras listesine girmiş değerlerin fiyatının daha yüksek oranda arttığı belirtilmiştir. Ayrıca, bedel değişimleri 
üzerinde yapılan çalışmaların on yıllara yayılan zaman dilimleri süresince, farklı örnek alanları kapsayan geniş coğrafi alanlarda karşılaştırmalı değerlendirmeye olanak veren gerçek ve kaydedilmiş verilerle gerçekleştirildiği görülmektedir. Bunun yanı sıra, bu araştırmalarda da vurgulandığı şekilde, korumaya yönelik olarak toplumda yerleşmiş algı ve duyarlılığın yüksekliği ve tescil kararları ve koruma uygulamalarına olan ilginin kentsel alandaki aktörlerden olan olumlu karşıı̆̆ın dikkat çekici olduğu vurgulanmalıdır.

Bu makalede, Talas kentsel sit alanı örneğinde emlak değerleme yöntemlerinin uygulanması ile kentsel sit alanlarında yer alan taşınmazların ekonomik değerleri üzerinde ortaya çıkan değişimin belirlenmesi amaçlanmıştır. Çalışmada, sit alanında belirlenmiş örnek alanlarda, 2012 yılında profesyonel değerleme şirketince yapılmış değerleme işlemi sonucunda tespit edilmiş olan ekonomik değerlerin, aynı şekilde 2019 yılı değerleri ile kıyaslanarak değişimin ortaya konulması hedeflenmiştir. Bu değişimin saptanabilmesi için, makalede öncelikle başlıca klasik yöntemler ve modern yöntemler olarak uygulanan değerleme yöntemleri konusunda bilgi verilmiş, sonrasında ülkemiz değerleme piyasası içinde en yaygın kullanılan klasik yöntemlerden olan Emsal Karşılaştırma Yöntemi ve Maliyet Yöntemi ayrı ayrı kullanılarak taşınmazların ekonomik değerlerinin değişimi ortaya konmuştur.

\section{Talas ve Koruma Alanları}

Cumhuriyet dönemine kadar çok kültürlü sosyal yapının bir sonucu olarak canlı ve dinamik bir yerleşme olarak yaşamını sürdüren Talas, Cumhuriyetin ilanı sonrasında 20. Yüzyıl içinde bu niteliğini göreli olarak kaybetmiş; yine de Kayseri kent merkezine yakınlığııın sağladığı avantajlarla büyümesini sürdürmüştür. 20. Yüzyıl içinde kentsel gelişme seyrinin durağanlığı, Talas'ın geçmişte elde etmiş olduğu miras birikimi üzerindeki değişme/dönüşme/yok olma riskini azaltmış, böylece miras üzerinde kentleşmeye dayalı kayıpların ya da bozulmaların etkisi az düzeyde olmuştur. Talas'ın yeni yerleşim alanlarının eski dokunun olduğu alanlar yerine yeni imar alanlarında ve Kayseri yönüne doğru oluşu mirasın yaşama olanaklarını artırmıştır. Ancak bu kez mirasa karşı ilgi kaybı ve yerleşmede kullanıı niteliklerinde değişim gerçeği ile karşı karşıya kaIınmıştır. Özetlenen bu gelişme süreci içinde Talas mirasının korunma durumunun yine de yüksek düzeyde olduğunu söylemek mümkündür.

20. Yüzyılın sonlarında Talas, kentleşme sürecinde yeni bir döneme girmiştir. Kayseri kentinin metropolitenleşme sürecinin hızlanması ve Erciyes Üniversitesi'nin Talas sınırında büyümesi Talas'ı canlandırmış, yeni oluşan kentsel alanlarda yapı ve nüfus yoğunluğu artırmıştır. Bu süreçte, Talas mirasında ciddi bir kayıp yaşanmamış ancak yeni konut alanları koruma alanlarının çok yakın komşuluğunda görülmeye başlanmıştır.
Son yirmi yıl içinde Kayseri metropoliten merkezinin büyüme ve gelişme alanı içinde kalan ve bu süreçte nüfusunu 30 binlerden 163.773 kişiye çıkaran Talas; kentleşme hızı ve imar piyasası açısından (özellikle konut sektöründe) metropoliten alanda en hızlı büyüyen yerleşme olmuştur. Kayseri merkeziyle bütünleşme sürecinde batı ve kuzey yönünde oluşan mekânsal büyüme, yıkıcı imar faaliyetlerini konum olarak doğu ve güney yönde kalan kentsel sit alanından uzak tutmuş, ancak kentsel sit alanı sınırına kadar gelen yoğun ve yüksek katlı yapılaşmaya engel olamamıştır. Bu kentleşme süreci sonrasında Talas yerleşmesinde taşınmaz değerlerinin oldukça yükselmiş olduğu açıktır. Sit alanında yer alan taşınmazlarda oluşan değer değişiminin daha açık bir şekilde yorumlanabilmesi için, makale kapsamında değerleme ölçümleri hem kentsel sit alanında hem de Talas'ın yoğun kentleşen alanlarında ayrı ayrı gerçekleştirilmiştir.

Talas yerleşmesinde, toplam yaklaşık 76 hektar büyüklüğe sahip, kentsel, doğal ve arkeolojik sit alanı olmak üzere üç farklı sit statüsü bulunmaktadır (Yılmaz, 2005). 2012 Yilında Talas Belediyesi yenilenen Talas İmar Planı'nda bu üç alanın yakın çevresi de sit alanına önerilmiş ve bu yeni sınırlar içinde 2016 yılında Talas Koruma Amaçlı Revizyon İmar Planı çalışmalarına başlanmıştır (Şekil I). Revizyon KAiP süreci halen devam ettiğinden, 2012-2019 yılları arasında önerilen revizyon alan sınırı içinde kapsamlı bir imar değişikliği yaşanmamıştır.

Kentsel sit alanı olarak tescil edilmiş alan, I. Derece Arkeolojik Sit sınırlarından Yukarı Talas yamaçları boyunca uzanan eğimli arazinin bir bölümünü ve çevresini kapsamaktadır (Şekil 2). Söz konusu bölgede daha çok Cumhuriyet dönemi sonrası kentten ayrılan Ermenilere ait yapılar yer almaktadır. 2. Derece Doğal sit alanı olarak tescillenen alan Ali Dağı etekleri ile Talas içinde bulunan vadi arasında uzanmaktadır ve doğal karakterini büyük ölçüde korumaktadır. Arkeolojik sit alanı olarak tescil edilmiş alan ise Ali Dağı'nın eteğinde 2 hektar büyüklüğe sahiptir. Bu alanda Roma dönemine ait bir yer altı şehri bulunmaktadır (Yılmaz, 2005).

Kentleşme süreci sonunda günümüzde, koruma alanı sınırlarının kuzeyinde ve batısında çok katlı apartman tipi yapılaşmaların oluştuğu, güneyinde ve doğusunda ise geleneksel karakterde bağ-bahçe tipi yerleşme dokusunun olduğu görülmektedir. Sit alanının da kendi içinde farklılaşarak kentsel alana daha çok temas eden kuzey-batı hattında tarihsel özelliğini nispeten koruduğu ancak güney bölgesinde villa tipi yapılaşmaların yer tuttuğu görülmektedir. Günümüzde kentsel sit alanı içinde yeni inşaat faaliyeti görülmemektedir.

\section{Değerleme Yöntemleri}

Bir taşınmazın belirli bir kısmının ya da tamamının nakdi değerini orta koymak için gerçekleştirilen ve niteliksel ya da 


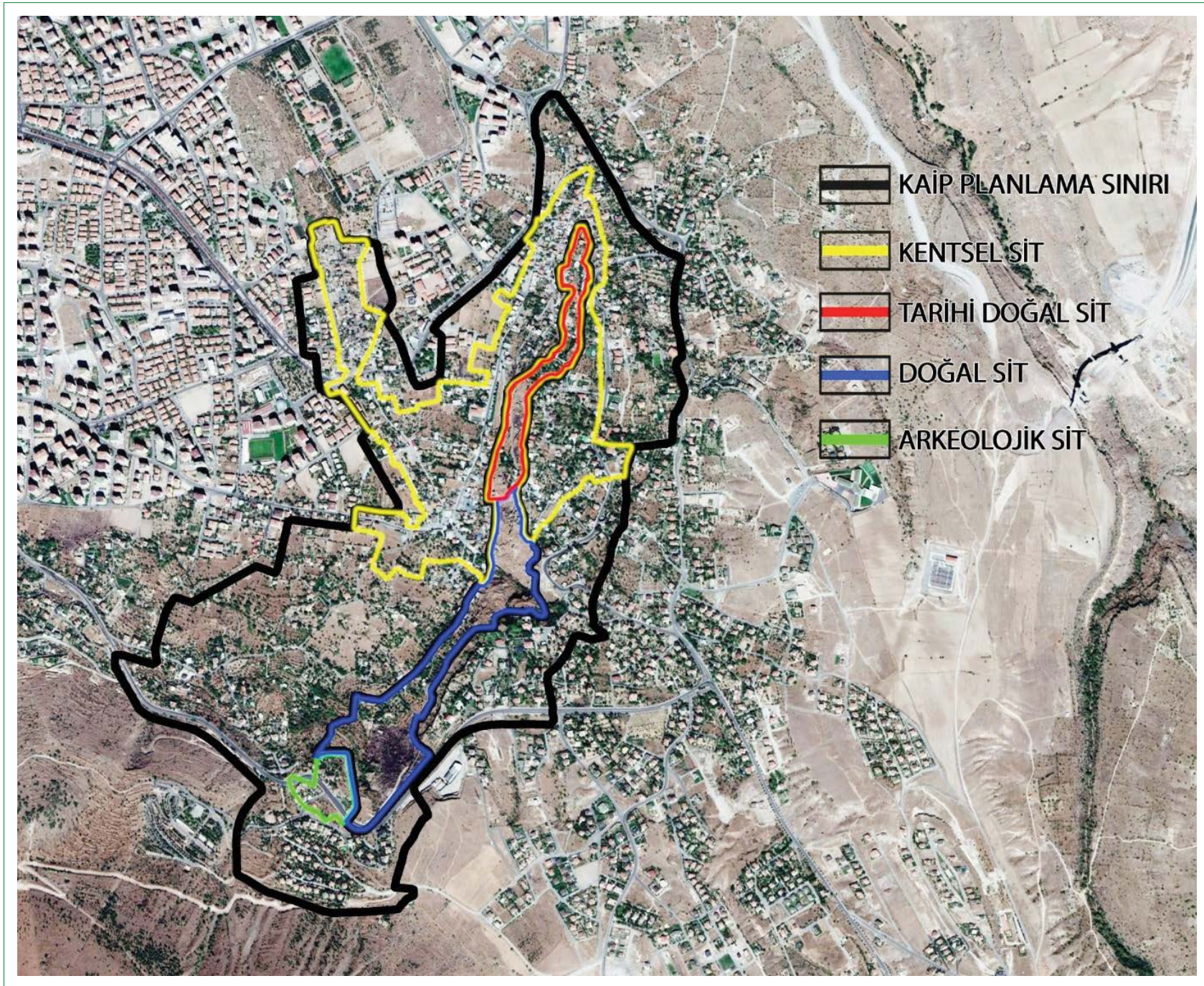

Şekil I. Talas sit alanları.

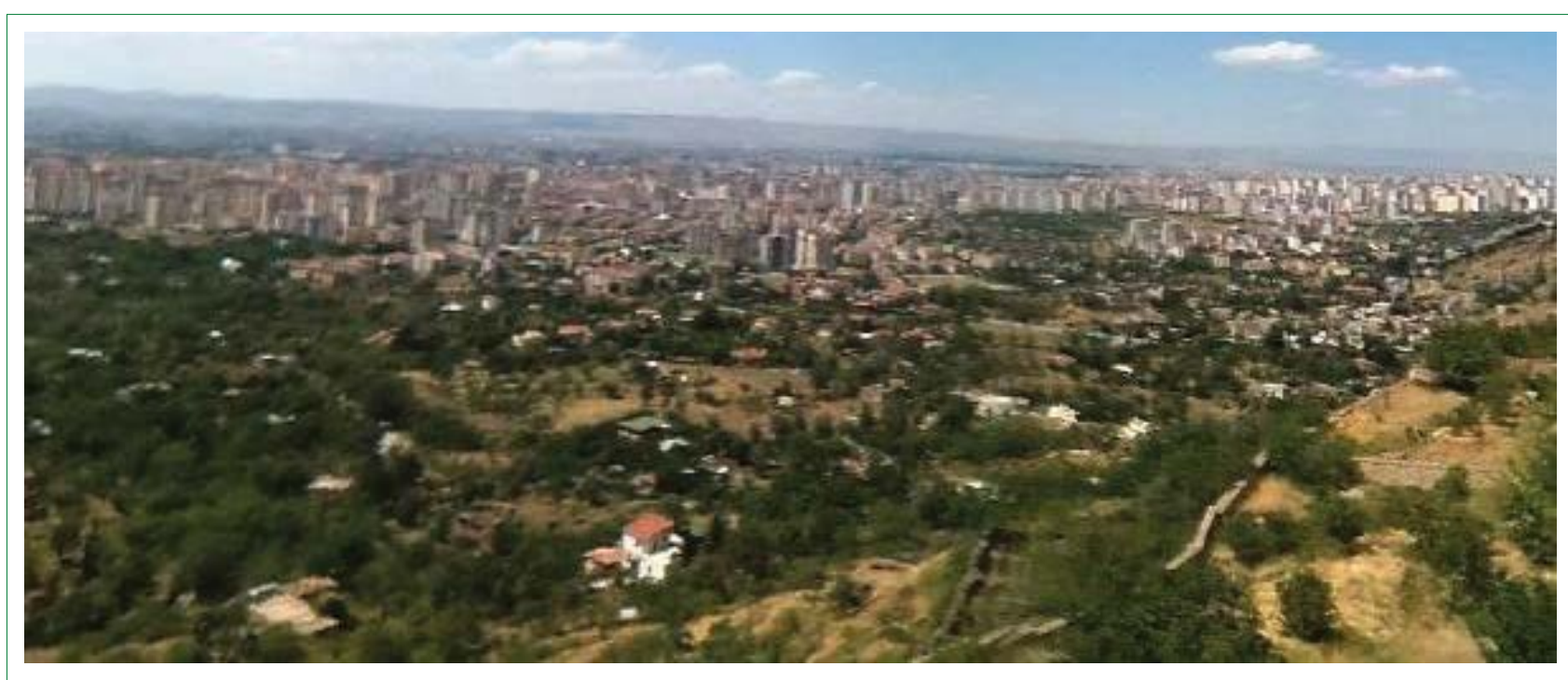

Şekil 2. Kentsel sit alanı cevresinde yeni kentsel oluşumlar. 
niceliksel olarak uygulanan yöntemler bütününe taşınmaz değerlemesi denmektedir. Taşınmaz değerlemesi; vergilendirme, özelleştirme ve kamulaştırma gibi devletin haklarını koruyan işlemlerin yanı sıra sermaye piyasası mevzuatı uyarınca bankacılık ve sigortacılık gibi özel teşebbüs gereksinimleri içinde kullanılan, birçok disiplinin ortak çalışmasını gerektiren bir uzmanlık alanıdır (Çakır ve Sesli, 20।3). Son yıllarda sermaye piyasası araçlarının taşınmazlar bağlamında özelleşmesi, beraberinde bu araçların dayanağı olan taşınmaz piyasalarının da denetimi ihtiyacını doğurmuştur. Bu denetimin temel yolu taşınmaz değerlerinin objektif ve bilimsel olarak değerlendirilmesidir. Bu kapsamda, değerleme uygulamaları gerçekleştirilmesinde geleneksel, modern ve istatistiksel olmak üzere başlıca üç temel yöntemin kullanıldığı görülmektedir (Yalpır, 2007).

Bu çalışma kapsamında da kullanılan "emsal karşılaştırma” yöntemi yanında "maliyet analizi" ve "gelir indirgeme" yöntemleri geleneksel değerleme yöntemler kategorisinde yer almakta en sık kullanılan yöntemler olarak dikkat çekmektedirler. Gelişen teknolojilerin birbiri ile entegre yapısının sağladığı olanaklarla daha fazla analiz verisine dayanarak değerleme yapma olanağı sunan yurtdışında ve akademik çalışmalarda yoğun olarak kullanılan modern değerleme yöntemlerinin en bilinenleri "yapay sinir ağları", "bulanık mantık", "konumsal analiz" ve "destek vektör makineleri regresyonu” gibi yöntemlerdir. Taşınmaz değeri ve taşınmaz kriterleri arasındaki sayısal ya da oransal bağıntılar ile matematiksel modeller oluşturmaya dayanan ve hem geleneksel hem modern değerleme yöntemlerinin avantajlarını bir araya getiren istatistiki değerleme yöntemlerinin başlıcaları "çoklu regresyon”, "hedonik yaklaşım” ve "nominal yöntemler"dir (Değerleme yöntemlerine ilişkin daha kapsamlı bilgi için bkz. Yomralıŏlu, 1997; Alkay, 2002; Çomak, 2004; Nişancı, 2005; Yıldırım, 2005; Nuhoğlu, 2007; Yalpır, 2007; Özer, 20I0; Bulut, 20II; Erdem, 2016; Tanrıvermiş, 2016).

Emsal karşılaştırma yöntemi, değerlemesi yapılan taşınmaz ile karşılaştırılabilir nitelikte olan satılık ve satılmış taşınmazların fiyatları üzerinden yapılacak düzeltmelerle nihai değerin belirlenmesi yöntemidir (Yıldırım, 2005). Bu yöntem ancak değerlemesi yapılacak taşınmaz ile aynı veya benzer özelliklere sahip yeterli sayıda emsal taşınmaz bulunması ve gayrimenkul için güvenli sürüm değerinin var olması halinde kullanılabilir (Özer, 2010). Söz konusu yöntem genellikle gelir getirmeyen ya da üzerinde herhangi bir yapı bulunmayan taşınmazlar için kullanılmakla birlikte güvenilir ve karşılaştırmaya uygun yeterli sayıda benzer satılık taşınmazın bulunduğu her türlü mülk için uygulanabilir (Tanrıvermiş, 20l6). Bu yöntem tüm değerleme yöntemleri arasında en sık kullanılan ve tercih edilen yöntem olma özelliğine sahiptir ve Ülkemizde de değerleme piyasasında kullanılmaktadır.

\section{Talas Kentsel Sit Alanında ve Sit Dışı Alanda Taşınmaz Değerlerinin Değişimi}

Bu makalede, Talas kentsel sit alanında ve dışında kalan taşınmazlara ilişkin gerçek alım-satım değerleri üzerinden değer değişimleri incelenmiştir. Yerel bir değerleme firmasının 2012 yılında hazırlamış olduğu değerleme raporlarından firmanın izni doğrultusunda alınan veriler, 2019 yılında gerçekleştirilen değerleme çalışmaları ile kıyaslanmıştır. Bu kıyaslama yapılırken koruma alanı sınırları içinde yer alan üç, koruma alanı sınırları dışında yer alan yine üç farklı bölge örnek alan olarak belirlenmiştir. Bu örnek alanlarda seçilen taşınmazların gerçek alım-satım değerlerinin tespiti yapılırken bahse konu parsellerin imar durumları, yasal nitelikleri, bölgede yer alan benzer nitelikteki parsellerin değerleri, söz konusu gayrimenkullerin konumu, ulaşımı, bölgenin altyapı durumu, bölgede benzer niteliklerdeki satılık taşınmazların sayısı, bölgedeki taşınmazlara olan talep gibi etmenler göz önünde bulundurulmuş; bunlara ilave olarak söz konusu taşınmazların okul, sağlık tesisi vb. donatı alanlarına ve bölgeye ulaşımı sağlayan ana arterlere olan mesafesi dikkate alınmıştır

Çalışma kapsamında, koruma alanı sınırları içindeki ve dışındaki arsaların 2012 yılında resmi olarak belirlenmiş alım-satım değerleri, bu çalışma kapsamında 2019 yılı koşullarında yeniden hesaplanmış ve ortaya çıkan değişim karşılaştırılarak tartışılmıştır. Bu kapsamda, seçilen örnek alanlarda ortaya çıkan değer farklılıklarının tespiti için sit alanı içinde ve dışında 2012 yılında verileri sağlayan profesyonel değerleme firmasınca hazırlanmış raporlar arasından rastgele seçimler yapılmıştır.

Değerleme firmasından elde edilen eski tarihli birim değerler ile emsal karşılaştırma ve maliyet analizine dayalı olarak elde edilen arazilerin güncel tarihli birim değerleri, TL ve Avro bazında karşılaştırmalı analize tabi tutulmuştur. Güncel fiyat tespitinde maliyet analizi ile taşınmazlar üzerinde yapı yer alması durumunda yapı maliyetleri düşülmüş ve arsa değerlerine ulaşılmıştır. Arazilerin güncel değerleri hesaplanırken her iki yönteme göre ayrı ayrı tahmin yapılmış ancak her iki yöntemle de yaklaşık olarak aynı değere ulaşıldığından değerleme tablolarında sadece tek değere yer verilmiştir. Emsal karşılaştırma yöntemi için bölgedeki satılık taşınmazlar analiz edilmiş ve uyumlaştırma sonrasında taşınmazların güncel değerleri için birim fiyatlar oluşturulmuştur. Çalışma kapsamında TL ve Avro olarak farklı değer tespiti yapılmasından beklenen, Ülkemizde bir yatırım enstrümanı olarak görülen gayrimenkul piyasasının olası yatırım araçlarına karşı dayanıklılığının ortaya koyulması olmuştur.

Çalışma kapsamında, sit alanı içinde ve dışında 300'er metre çaplı 3'er adet örnek alan seçilmiştir. Alanların tespitinden sonra yerel düzeyde yapılan ilk araştırmaya alanların vergiye esas asgari değerleri bulunmuştur. Ancak vergiye esas değerlerin, örnek taşınmazların güncel ve gerçek piyasa değerinin oldukça altında kaldığı görülmüş ve bu nedenle çalışma 


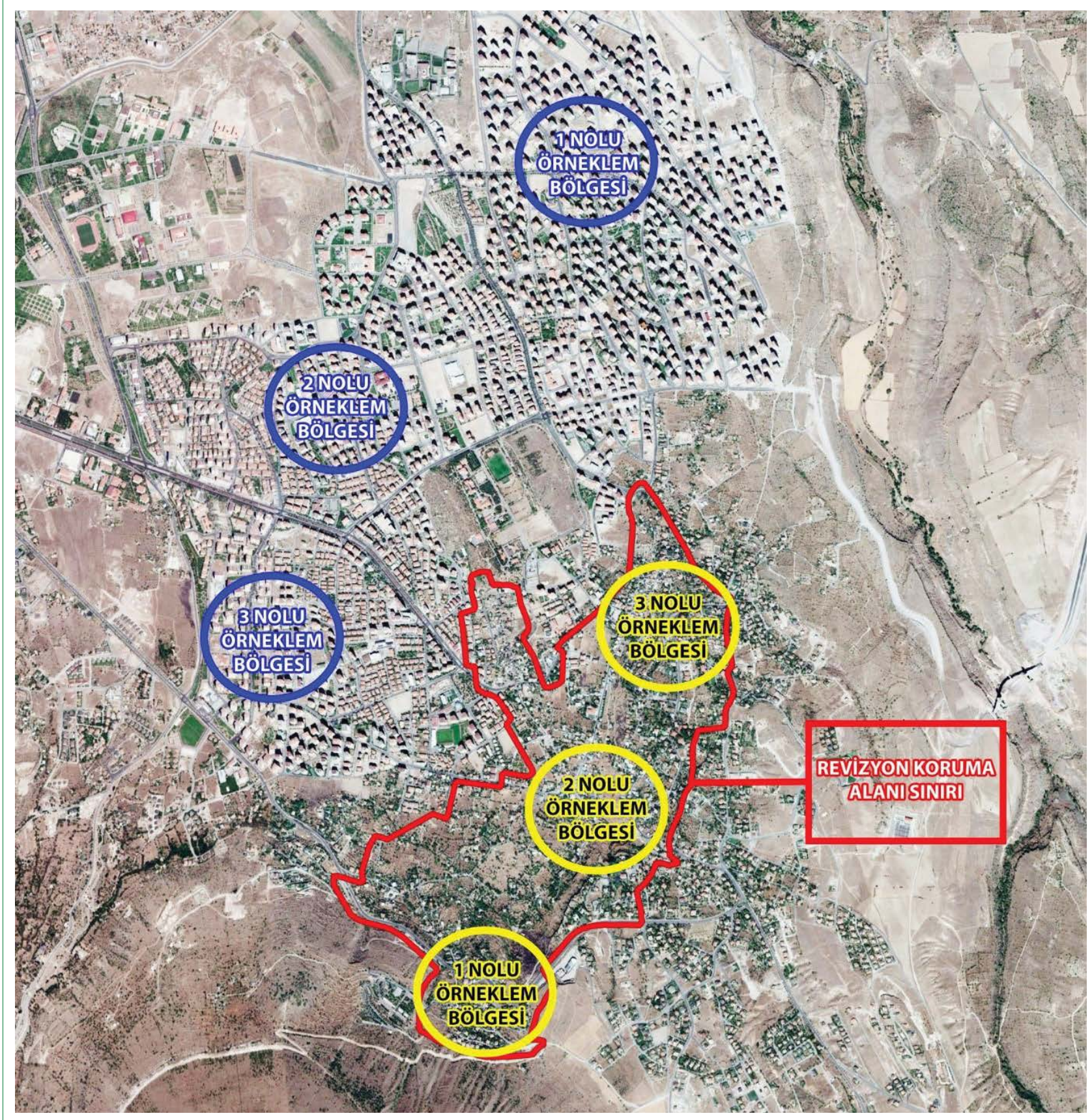

Şekil 3. Çalışmada incelenen örnek alanlar.

kapsamına alınmamıştır. Bölgede yeterli görülebilecek miktarda sayıda güvenilir ve karşılaştırılabilir emsal bulunduğundan ve uygun örneklerin bulunması durumunda literatürde değer tespiti için en uygun ve temel yaklaşım olduğu ifade edildiğinden (Yıldırım, 2005) emsal karşılaştırma yöntemi, bu çalışmada değerlendirme yöntemi olarak kullanılmıştır.

Emsal karşılaştırma yöntemi uyarınca tespit edilen değerleri ekonomik faktörler bağlamında sağlıklı yorumlayabilmek adına değer artış yüzdeleri enflasyon, Avro ve Hedonik Konut
Fiyat Endeksi (HKFE) verileri ile kıyasa tabi tutulmuştur. Bu kıyaslama için 2012-2019 yılları arasında ilgili verilerin değişim yüzdeleri bulunmuş ve değer değişim yüzdeleri ile aralarındaki getiri oranları hesaplanmıştır. Söz konusu değişim yüzdeleri, ilgili yıllar arasında TCMB'nin enflasyon hesaplayıcısına göre TÜFE'de $+\% 92$, Avro paritesinde $+\%$ I83, HKFE değişiminde +\% I I 0 olarak görülmektedir.

Çalışma kapsamında sit alanında seçilen örnek alanlardan birincisi Ali Dağı eteklerinde ikinci konut yapılarının bulunduğu 

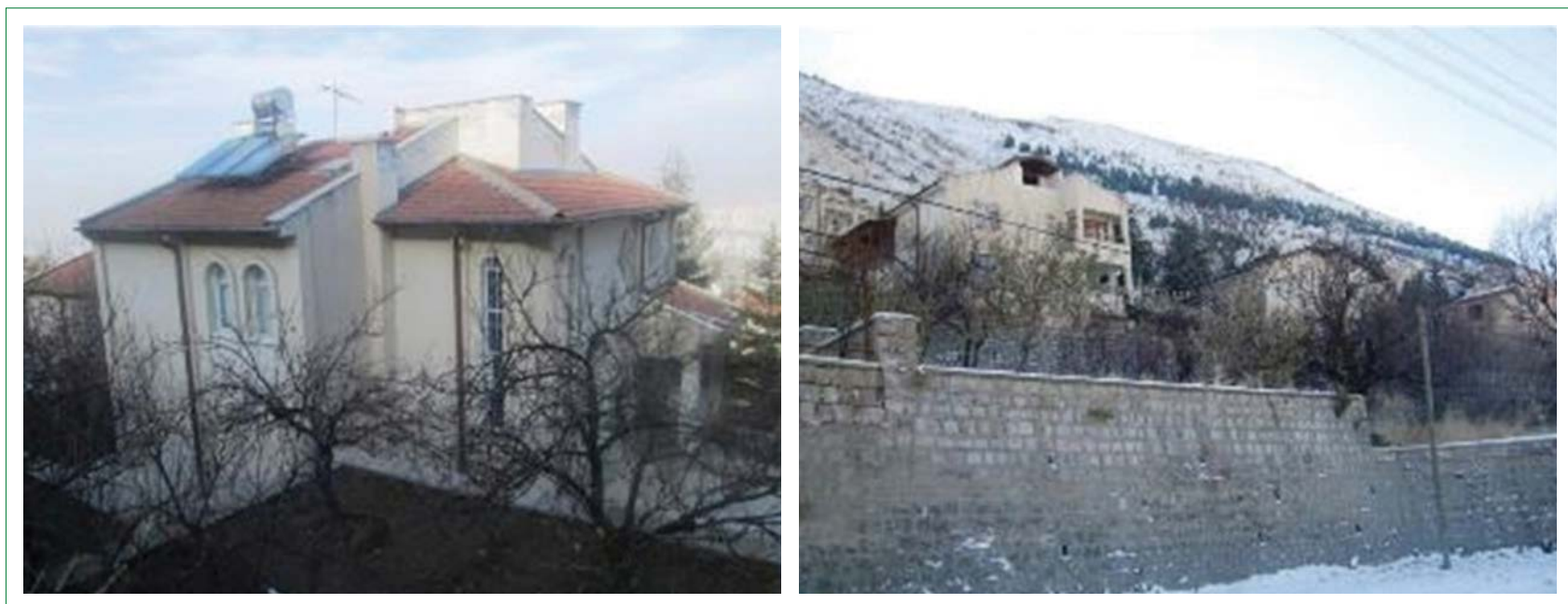

Şekil 4. KI örnek alanından görüntüler.

Tablo I. KI örnek alanı değerleme tablosu

\begin{tabular}{|c|c|c|c|c|c|c|c|c|c|c|}
\hline İşlev & $\begin{array}{c}\text { Yüzölçüm } \\
\left(\mathbf{m}^{2}\right)\end{array}$ & TAKS & KAKS & $\begin{array}{l}\text { İnşaat alanı } \\
\left(m^{2}\right)\end{array}$ & $\begin{array}{l}2012 \text { değeri } \\
\text { (TL) }\end{array}$ & $\begin{array}{l}2012 \text { birim } \\
\text { fiyatı }\left(\mathrm{TL} / \mathrm{m}^{2}\right)\end{array}$ & $\begin{array}{l}2019 \text { değeri } \\
\text { (TL) }\end{array}$ & $\begin{array}{l}2019 \text { birim } \\
\text { fiyatı (TL) }\end{array}$ & $\begin{array}{l}\text { Fiyat farkı } \\
\text { (TL) }\end{array}$ & $\begin{array}{c}\text { Fiyat farkı } \\
(\%)\end{array}$ \\
\hline Konut & 1.109 & 0,25 & 0,50 & 554,5 & 275.000 & 496 & 506.000 & 913 & 231.000 & 84 \\
\hline Konut & 1.020 & 0,25 & 0,50 & 510 & 205.000 & 402 & 385.000 & 755 & 180.000 & 88 \\
\hline Konut & 1.098 & 0,25 & 0,50 & 549 & 195.000 & 355 & 391.000 & 712 & 196.000 & 101 \\
\hline Konut & 1.439 & 0,10 & 0,20 & 287,8 & 130.000 & 452 & 270.000 & 938 & 140.000 & 108 \\
\hline Konut & 1.440 & 0,10 & 0,20 & 288 & 100.000 & 347 & 215.000 & 747 & 115.000 & 115 \\
\hline Konut & 1.030 & 0,12 & 0,24 & 247,2 & 115.000 & 465 & 242.000 & 979 & 127.000 & 111 \\
\hline Konut & 1.006 & 0,12 & 0,24 & $24 I, 44$ & 110.000 & 456 & 220.000 & 911 & 110.000 & 100 \\
\hline Konut & 2.758 & 0,10 & 0,20 & 551,6 & 340.000 & 616 & 721.000 & 1307 & 381.000 & 112 \\
\hline Konut & 1.013 & 0,12 & 0,24 & 243,12 & 150.000 & 617 & 297.000 & 1222 & 147.000 & 98 \\
\hline Konut & 1.044 & 0,25 & 0,50 & 522 & 160.000 & 307 & 352.000 & 674 & 192.000 & 120 \\
\hline Konut & 1.439 & 0,10 & 0,20 & 287,8 & 80.000 & 278 & 160.000 & 556 & 80.000 & 100 \\
\hline Konut & 1.006 & 0,12 & 0,24 & $24 I, 44$ & 90.000 & 373 & 187.000 & 775 & 97.000 & 108 \\
\hline
\end{tabular}

bölge; ikincisi, bu bölgenin merkezinde ve doğal sit alanının çeperinde yine az katlı yapıların bulunduğu yer alan bölge; üçüncüsü ise Mevlana mahallesi çeperinde yoğun kentleşmenin en çok etkisi altında olan bölgeden seçilmiştir. Bu alanlar çalışmada sırasıyla KI, K2 ve K3 rumuzlarıyla ifadelendirilmiştir. Sit alanı dışında belirlenen birinci örnek alan, Mevlana mahallesinde 15 katlı yapıların bulunduğu alan; ikinci örnek alan Yenidoğan mahallesinde bulunan, 6-8 katlı yapıların bulunduğu ve sıklıkla dönüşüm projeleri ile adı anılan merkezi bölgeden; üçüncü örnek alan ise Bahçelievler mahallesinde 10-12 katlı yapıların bulunduğu daha çok üst gelir grubuna hitap eden konutların bulunduğu bölge olarak seçilmiştir. Söz konusu bölgeler çalışmada sırasıyla MI, M2 ve M3 rumuzlarıyla ifadelendirilmiştir (Şekil 3).

$\mathrm{Bu}$ alanların belirlenirken kentsel sit alanı içinde üzerinde tescil kaydı bulunmayan, yeni yapı yapımına uygun boş ya da yapılaşmış parsellerin belirlenmesi sağlanmıştır. Kentsel sit dışında ise Talas'ın yakın dönemde kentleşmiş, yapılaşma ve nüfus yoğunluğu yüksek olan noktalar belirlenmiştir. Talas'ın, Kayseri kent merkezinin çok yakın etki alanı içinde olması ve Talas'ta ikamet edip Kayseri'ye günlük çalışmaya giden nüfusun yoğunluğu nedeniyle sit dışında örnek alanların belirlenmesinde Kayseri merkeze olan mesafe de dikkate alınmıştır. Hesaplamalar sonrasında 2012 ve 2019 değerleri ilgili tablolarda gri zeminle belirtilerek karşılaştırma kolaylığı sağlanmaya çalışılmıştır.

\section{I. KI Örnek Alanı}

$\mathrm{KI}$ örnek alanı, Kayseri kent merkezinin güneydoğusunda ve $8 \mathrm{~km}$. mesafede yer alan, ikinci konut karakterli 2-3 katlı yapılardan oluşan ve kentsel sit alanının genel karakterinden farklı 


\begin{tabular}{|l|c|c|c}
\hline Ortalama değer değişimi (\%) & 103,75 & \multicolumn{2}{|c}{$2012-2019$} \\
\hline Avro bazında getiri oranı (\%) & -43 & Avro değişim yüzdesi & 183 \\
\hline Enflasyon bazında getiri oranı (\%) & 13 & Enflasyon değişim yüzdesi & 92 \\
\hline HKFE bazında getiri oranı (\%) & -6 & HKFE değişim yüzdesi & 110 \\
\hline
\end{tabular}

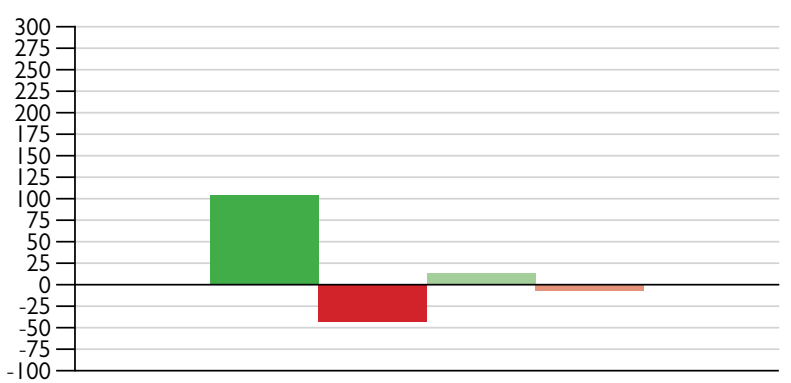

- Ortalama değer değişimi (\%) — Avro bazında getiri oranı (\%) Enflasyon bazında getiri oranı (\%) — HKFE bazında getiri oranı (\%)

Şekil 5. KI örnek alanında taşınmazların 20I2-20I9 değer değişimleri.

olarak 1980'li yıllarda inşa edilmiş müstakil evlerden oluşan bölgedir (Şekil 4). Kolay ulaşılan alanda ve çevresinde Ali Dağı Mesire Alanı ve Talas Seyirtepesi bulunmaktadır.

Söz konusu alanda güncel değerlemesi yapılabilir durumda, imar ve kullanım niteliği değişmemiş 12 adet parsel tespit edilmiş ve emsal karşılaştırma yöntemi ışığında imar ve konum özellikleri dikkate alınarak 2019 yılı için güncel birim değerleri tespit edilmiştir. Bu parsellerin tamamının imar fonksiyonunun konut olduğu, yapılaşma taban alanı kat sayılarının 0.10 ile 0.25 oranında değiştiği, yapılaşma kat alanı kat sayılarının 0.20 ile 0.50 oranında değiştiği tespit edilmiştir. Örnek olarak seçilen parsellerin TAKS ve KAKS değerleri arasında büyük bir farklılık bulunmamasına karşın doğru ve uygun karşılaştırma yapabilmek adına inşaat alanlarının $\mathrm{m}^{2}$ başına düsen değerleri üzerinden kıyaslama yapılmıştır (Tablo I).
2012 yılında hazırlanan değerleme raporlarında, örnek seçilen arsaların inşaat alanı $\mathrm{m}^{2}$ birim fiyatlarının $278 \mathrm{TL}$ ile 617 TL arasında olduğu tespit edilmiştir. 2019 yılında tarafımızca yapılan değerleme çalışmasında örnek alan inşaat alanı $\mathrm{m}^{2}$ birim fiyatlarının 556 TL ile 1307 TL arasında olduğu bulunmuştur. Taşınmazların 2012'den 2019 yılına kadar yaşadıkları değer değişimin ortalaması $+\% 103,75$ olarak ortaya çıkmaktadır. Bu oran tek başına pozitif yönde kâr olarak görülebilmekte iken, Türkiye'nin bu süreçte yaşadığı ekonomik değişimler ile kıyaslanması farklı sonuçları göstermektedir. Bu orana göre ilgili bölgedeki taşınmazlar 2012-2019 yılları arasındaki enflasyon karşısında yaklaşık olarak \% I 3 oranında getiri yaratırken, Avro karşısında \%43, HKFE karşısında \%6 getiri kaybı yaratmıştır (Şekil 5). Her üç oran da incelendiğinde enflasyonist ekonomik şartlar altında arsa değerlerinde reel olarak belirli bir oranda artış görülmesine karşın koruma alanı sınırları içindeki KI alanında alım-satım değerlerinde kayıp yaşandığı ortaya konulmuştur.

\subsection{K2 Örnek Alanı}

K2 örnek alanı, halk arasında Eski Talas olarak da adlandırılan Yukarı Talas bölgesinde, Kayseri kent merkezinin güneydoğusunda ve yaklaşık $8 \mathrm{~km}$ mesafede bulunmaktadır. Alandaki yapılar geleneksel taş yapılar olup koruma alanının genel karakterine uygun olarak 1800 'lü yıllarda inşa edilmiş müstakil evlerden oluşmaktadırlar (Şekil 6). Alana ulaşım kolaydır.

K2 örnek alanında güncel değerlemesi yapılabilir durumda, imar ve kullanım niteliği değişmemiş on adet parsel tespit edilmiş olup emsal karşılaştırma yöntemi ışı̆̆ında imar ve konum özellikleri dikkate alınarak 2019 yılı için güncel birim değerleri tespit edilmiştir. Parsellerin tamamının imar fonksiyonunun konut olduğu, yapılaşma taban alanı kat sayılarının 0.10 ile 0.30 oranında değiştiği, yapılaşma kat alanı kat sayılarının 0.20 ile 0.60 oranında değiştiği tespit edilmiştir. Örneklem olarak alınan parsellerin TAKS ve KAKS değerleri arasında büyük bir

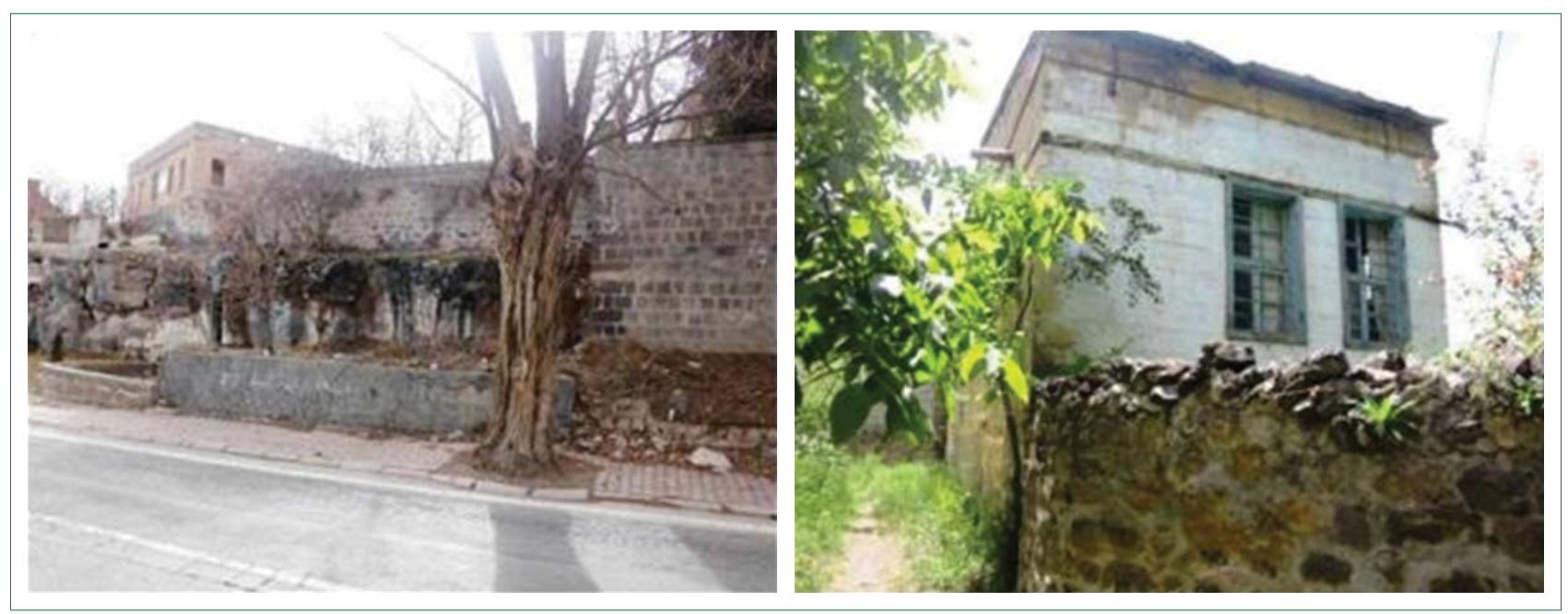

Şekil 6. K2 örnek alanından görüntüler. 
Tablo 2. K2 örnek alanı değerleme tablosu

\begin{tabular}{|c|c|c|c|c|c|c|c|c|c|c|}
\hline İşlev & $\begin{array}{c}\text { Yüzölcçüm } \\
\left(m^{2}\right)\end{array}$ & TAKS & KAKS & $\begin{array}{l}\text { İnşaat alanı } \\
\left(m^{2}\right)\end{array}$ & $\begin{array}{l}2012 \text { değeri } \\
\text { (TL) }\end{array}$ & $\begin{array}{l}2012 \text { birim } \\
\text { fiyatı }\left(\mathrm{TL} / \mathrm{m}^{2}\right)\end{array}$ & $\begin{array}{l}2019 \text { değeri } \\
\text { (TL) }\end{array}$ & $\begin{array}{l}2019 \text { birim } \\
\text { fiyatı (TL) }\end{array}$ & $\begin{array}{l}\text { Fiyat farkı } \\
\text { (TL) }\end{array}$ & $\begin{array}{l}\text { Fiyat fark } \\
(\%)\end{array}$ \\
\hline Konut & 2.012 & 0,12 & 0,24 & 482,88 & 760.000 & 1.574 & 1.375 .000 & 2.847 & 615.000 & 81 \\
\hline Konut & 2.411 & 0,12 & 0,24 & 578,64 & 560.000 & 968 & 1.045 .000 & 1.806 & 485.000 & 87 \\
\hline Konut & 1.310 & 0,12 & 0,24 & 314,4 & 245.000 & 779 & 512.000 & 1.628 & 267.000 & 109 \\
\hline Konut & 2.275 & 0,12 & 0,24 & 546 & 395.000 & 723 & 825.000 & 1.511 & 430.000 & 109 \\
\hline Konut & 1.250 & 0,12 & 0,24 & 300 & 265.000 & 883 & 495.000 & 1.650 & 230.000 & 87 \\
\hline Konut & 1.004 & 0,12 & 0,24 & 240,96 & 345.000 & 1.432 & 693.000 & 2.876 & 348.000 & 101 \\
\hline Konut & 2.011 & 0,12 & 0,24 & 482,64 & 695.000 & 1.440 & 1.430 .000 & 2.963 & 735.000 & 106 \\
\hline Konut & 739 & 0,12 & 0,24 & 177,36 & 140.000 & 789 & 314.000 & 1.770 & 174.000 & 124 \\
\hline Konut & 1.461 & 0,10 & 0,20 & 292,2 & 195.000 & 667 & 429.000 & 1.468 & 234.000 & 120 \\
\hline Konut & 200 & 0,30 & 0,60 & 120 & 65.000 & 542 & 154.000 & 1.283 & 89.000 & 137 \\
\hline
\end{tabular}

\begin{tabular}{|l|c|c|c}
\hline \multicolumn{4}{|c}{} \\
\hline Ortalama değer değişimi (\%) & 106,1 & \multicolumn{2}{|c}{$2012-20 । 9$} \\
\hline Avro bazında getiri oranı (\%) & -42 & Avro değişim yüzdesi & 183 \\
\hline Enflasyon bazında getiri oranı (\%) & 15 & Enflasyon değişim yüzdesi & 92 \\
\hline HKFE bazında getiri oranı (\%) & -4 & HKFE değişim yüzdesi & 110 \\
\hline
\end{tabular}

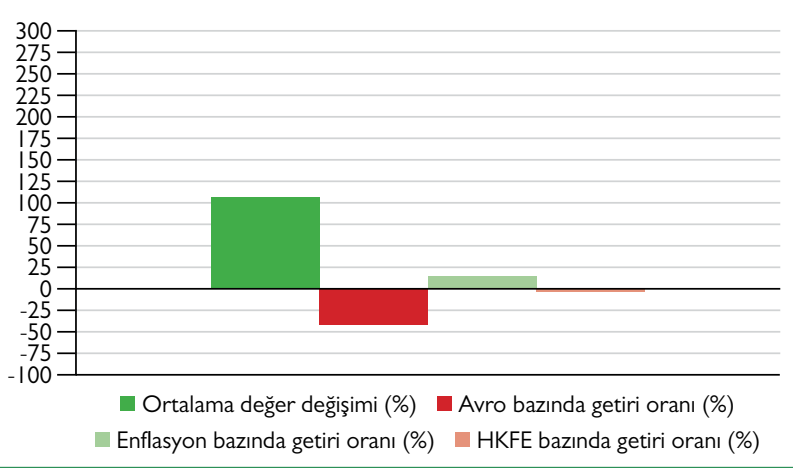

Şekil 7. K2 örnek alanında taşınmazların 20I2-20I9 değer değişimleri.

farklılık bulunmamasına karşın doğru ve uygun karşılaşırma yapabilmek adına inşaat alanlarının $\mathrm{m}^{2}$ birimine düsen değerleri üzerinden kıyaslama yapılmışıtır (Tablo 2).

2012 yılında hazırlanan değerleme raporlarında K2 örnek alanındaki inşaat alanı $\mathrm{m}^{2}$ birim fiyatlarının $542 \mathrm{TL}$ ile $1574 \mathrm{TL}$ arasında olduğu, 2019 yılı değerleme çalışmasında ise bu fiyatların 1283 TL ile 2963 TL arasında olduğu tespit edilmiştir. Bu taşınmazlarda 2012-2019 arası değişim ortalaması +\%106.01 olarak gerçekleşmiştir. Bu oranlarla taşınmazlar reel olarak pozitif yönde değer artışı gösterirken, diğer parametreler açısından ele alındığında enflasyon karşısında \% I5 oranında getiri sağlamış, Avro karşısında \%42 ve HKFE karşısında ise \%4 değer kaybı göstermişlerdir (Şekil 7). Bu oranlar K2 örnek alanında, reel rakamlar ve enflasyonist şartlarda arsa değerlerinde belirli bir oranda artış görülmesine karşın alım-satım değerlerinde kaybın söz konusu olduğunu göstermektedir.

\subsection{K3 Örnek Alanı}

K3 örnek alanı, Kayseri kent merkezinin güneydoğusunda 7,5 $\mathrm{km}$ mesafede yer almaktadır. Örnek alanın çevresinde kısmen geleneksel dokuya ait yapılar kısmen de yeni yapılmış iki ya da üç katlı ikinci konut amaçlı yapılar bulunmaktadır (Şekil 8). Alan kolay ulaşılabilir konumdadır.

K3 örnek alanında güncel değerlemesi yapılabilir durumda, imar ve kullanım niteliği değişmemiş I I adet parsel tespit edilmiş ve emsal karşılaştırma yöntemi ışığında imar ve konum özellikleri dikkate alınarak 2019 için güncel birim değerleri tespit edilmiştir (Tablo 3).

K3 örnek alanında bulunan taşınmazların tamamının imar planında belirlenmiş kullanımlarının konut olduğu, taban alanı kat sayılarının 0.10 ve kat alanı kat sayılarının 0.20 olduğu görülmüştür. 2012 yılı değerleme raporlarında bölgede bulunan taşınmazların inşaat alanı $\mathrm{m}^{2}$ birim fiyatlarının $600 \mathrm{TL}$ ile $3263 \mathrm{TL}$ arasında değiştiği, 2019 yilında ise bu değerlerin I07I TL ile 5663 TL arasında olduğu tespit edilmiştir. Söz konusu arsaların 2012'den 2019 yılına yaşadıkları değişimin ortalamasının yaklaşık $+\% 88.91$ olduğu görülmüştür. Reel olarak artış ifade eden bu oranlara karşın, K3 örnek alanındaki taşınmazların enflasyon karşısında \%3, avro karşısında \%5। ve HKFE karşısında \% I9 değer kaybı gösterdiği görülmüştür (Şekil 9). Talas yerleşmesinin ve sit alanının, diğer örnek alanlara göre çeperinde yer almasının da etkisiyle, K3 örnek alanında her üç ekonomik parametre açısından 2012-2019 yılları arasında değer kaybının söz konusu olduğu görülmektedir.

\subsection{MI Örnek Alanı}

Kentsel sit alanı dışında belirlenen örnek alanlardan ilki olan ve halk arasinda Anayurt olarak bilinen kesimde yer alan MI örnek alanı, Mevlana mahallesinde Kayseri kent merkezinin güneydoğusunda $8 \mathrm{~km}$ mesafede bulunmaktadır. Alandaki ya- 


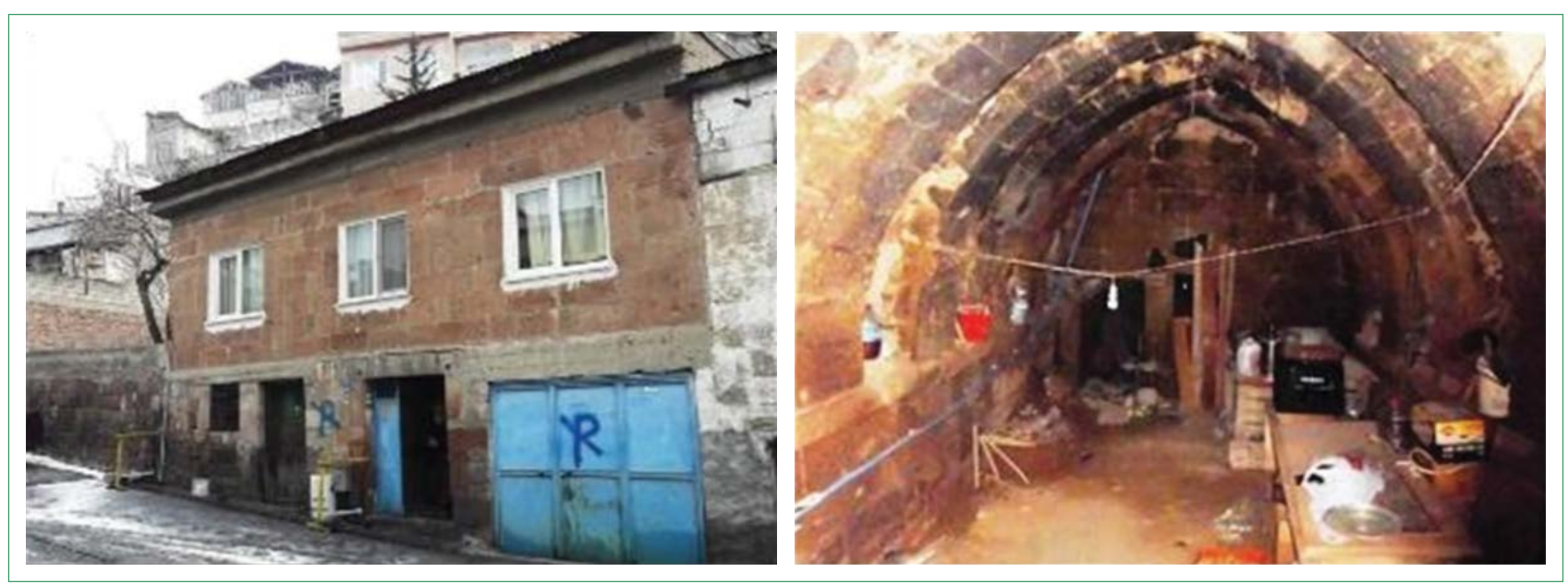

Şekil 8. K3 örnek alanından görüntüler.

Tablo 3. K3 örnek alanı değerleme tablosu

\begin{tabular}{lcccccccccc}
\hline Işlev & $\begin{array}{c}\text { Yüzölçüm } \\
\left(\mathbf{m}^{2}\right)\end{array}$ & TAKS & KAKS & $\begin{array}{c}\text { Inşaat alanı } \\
\left(\mathbf{m}^{2}\right)\end{array}$ & $\begin{array}{c}\mathbf{2 0 1 2} \text { değeri } \\
\mathbf{( T L )}\end{array}$ & $\begin{array}{c}\mathbf{2 0 1 2} \text { birim } \\
\text { fiyatı } \mathbf{( T L / \mathbf { m } ^ { 2 } )}\end{array}$ & $\begin{array}{c}\mathbf{2 0 1 9} \text { değeri } \\
(\mathbf{T L})\end{array}$ & $\begin{array}{c}\mathbf{2 0 1 9} \text { birim } \\
\text { fiyatı (TL) }\end{array}$ & $\begin{array}{c}\text { Fiyat farkı } \\
(\mathbf{T L})\end{array}$ & $\begin{array}{c}\text { Fiyat farkı } \\
(\%)\end{array}$ \\
\hline Konut & 167 & 0,10 & 0,20 & 33,4 & 33.500 & 1.003 & 64.000 & 1.916 & 30.500 & 91 \\
Konut & 164 & 0,10 & 0,20 & 32,8 & 34.000 & 1.037 & 64.000 & 1.951 & 30.000 & 88 \\
Konut & 145 & 0,10 & 0,20 & 29 & 31.000 & 1.069 & 61.000 & 2.103 & 30.000 & 97 \\
Konut & 752 & 0,10 & 0,20 & 150,4 & 135.000 & 898 & 244.000 & 1.622 & 109.000 & 81 \\
Konut & 475 & 0,10 & 0,20 & 95 & 310.000 & 3.263 & 538.000 & 5.663 & 228.000 & 74 \\
Konut & 134 & 0,10 & 0,20 & 26,8 & 31.500 & 1.175 & 56.000 & 2.090 & 24.500 & 78 \\
Konut & 129 & 0,10 & 0,20 & 25,8 & 28.500 & 1.105 & 56.000 & 2.171 & 27.500 & 96 \\
Konut & 837 & 0,10 & 0,20 & 167,4 & 275.000 & 1.643 & 527.000 & 3.148 & 252.000 & 92 \\
Konut & 695 & 0,10 & 0,20 & 139 & 210.000 & 1.511 & 472.000 & 3.396 & 262.000 & 125 \\
Konut & 5.962 & 0,10 & 0,20 & $1.192,4$ & 715.000 & 600 & 1.277 .000 & 1.071 & 562.000 & 79 \\
Konut & 3.508 & 0,10 & 0,20 & 701,6 & 455.000 & 649 & 80.5000 & 1.147 & 350.000 & 77 \\
\hline
\end{tabular}

pılar, çoğunlukla 2000'ler ve sonrasında inşa edilmiş 10-I5 arasında kat adedine sahip, zemin katları ticaret, üst katları ise konut olarak kullanılan yapılardır (Şekil 10). Alanın çevresinde Erciyes Üniversitesi 15 Temmuz Kampusu, Bir özel kolej ve TOKI Küme Evleri toplu konutu bulunmaktadır.

MI örnek alanında güncel değerlemesi yapılabilir durumda, imar ve kullanım niteliği değişmemiş 14 adet parsel tespit edilmiş ve emsal karşılaştırma yöntemi ışığında imar ve konum özellikleri dikkate alınarak 2019 yılı için güncel birim değerleri tespit edilmiştir. Parsellerden dördünün imar işlevi konut+ticaret, diğerlerininki ise konuttur. TAKS'lar, Kayseri'de yaygın olan kütle parsel uygulamasına bağlı olarak, tüm parsellerde 1.00 iken emsaller 10.00 ve 15.00 olarak ortaya çıkmıştır (Tablo 4).

2012 yılında hazırlanan değerleme raporlarında alandaki arsaların inşaat alanı $\mathrm{m}^{2}$ birim fiyatlarının $162 \mathrm{TL}$ ve $227 \mathrm{TL}$ olduğu

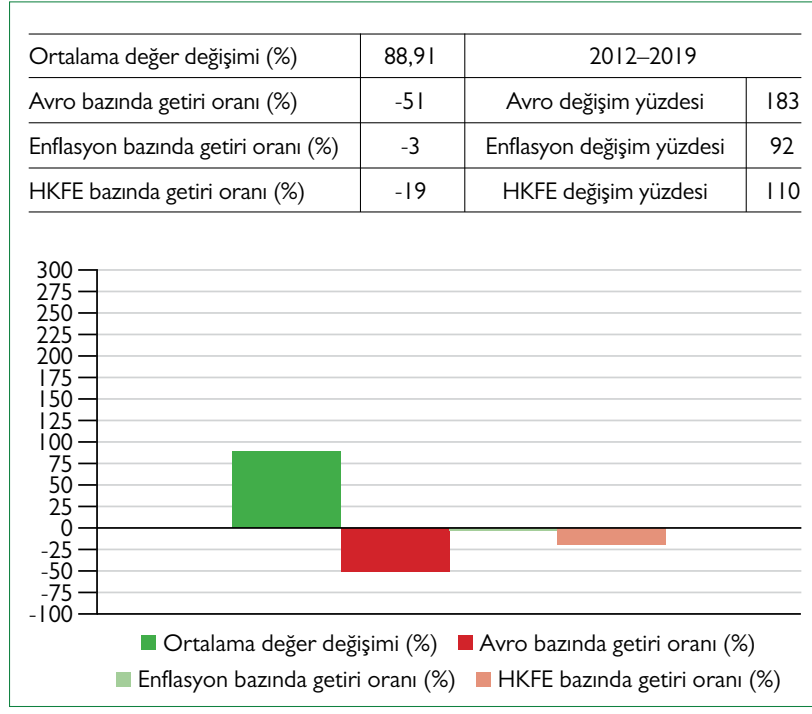

Şekil 9. K3 örnek alanında taşınmazların 2012-2019 değer değişimleri. 

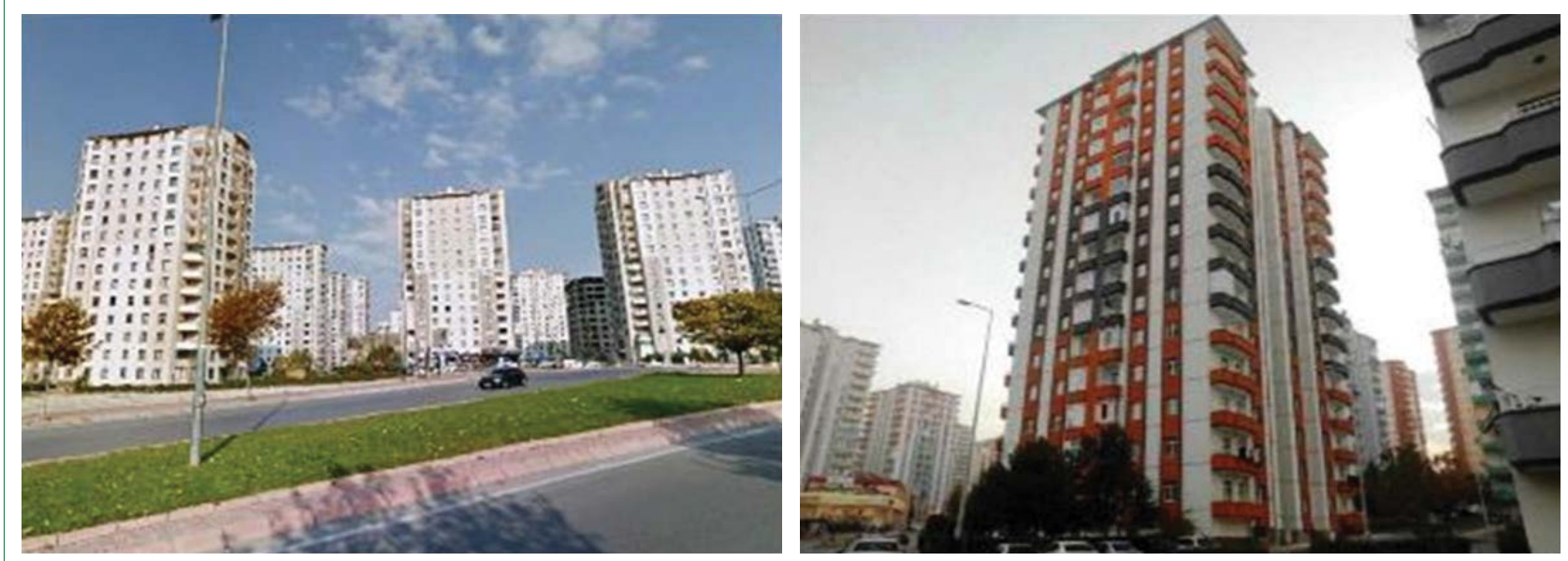

Şekil I0. MI örnek alanından görüntüler.

Tablo 4. MI örnek alanı değerleme tablosu

\begin{tabular}{|c|c|c|c|c|c|c|c|c|c|c|}
\hline İşlev & $\begin{array}{c}\text { Yüzölçüum } \\
\left(\mathbf{m}^{2}\right)\end{array}$ & TAKS & KAKS & $\begin{array}{c}\text { İnşaat alanı } \\
\left(m^{2}\right)\end{array}$ & $\begin{array}{l}2012 \text { değeri } \\
\text { (TL) }\end{array}$ & $\begin{array}{l}2012 \text { birim } \\
\text { fiyatı }\left(\mathrm{TL} / \mathrm{m}^{2}\right)\end{array}$ & $\begin{array}{l}2019 \text { değeri } \\
\text { (TL) }\end{array}$ & $\begin{array}{l}2019 \text { birim } \\
\text { fiyatı (TL) }\end{array}$ & $\begin{array}{l}\text { Fiyat farkı } \\
\text { (TL) }\end{array}$ & $\begin{array}{l}\text { Fiyat farkı } \\
(\%)\end{array}$ \\
\hline Konut & 535,5 & 1,00 & 15,00 & $8.032,5$ & 1.300 .000 & 162 & 5.175 .000 & 644 & 3.875 .000 & 298 \\
\hline \multicolumn{11}{|l|}{ Konut+ } \\
\hline Ticaret & 750 & $\mathrm{I}, 00$ & 10,00 & 7.500 & 1.700 .000 & 227 & 7.878 .000 & 1.050 & 6.178 .000 & 363 \\
\hline \multicolumn{11}{|l|}{ Konut+ } \\
\hline Ticaret & 750 & 1,00 & 10,00 & 7.500 & 1.700 .000 & 227 & 7.878 .000 & 1.050 & 6.178 .000 & 363 \\
\hline \multicolumn{11}{|l|}{ Konut+ } \\
\hline Ticaret & 750 & $\mathrm{I}, 00$ & 10,00 & 7.500 & 1.700 .000 & 227 & 7.878 .000 & 1.050 & 6.178 .000 & 363 \\
\hline Konut & 535,5 & $\mathrm{I}, 00$ & 15,00 & $8.032,5$ & 1.300 .000 & 162 & 5.175 .000 & 644 & 3.875 .000 & 298 \\
\hline Konut & 535,5 & 1,00 & 15,00 & $8.032,5$ & 1.300 .000 & 162 & 5.175 .000 & 644 & 3.875 .000 & 298 \\
\hline Konut & 535,5 & 1,00 & 15,00 & $8.032,5$ & 1.300 .000 & 162 & 5.175 .000 & 644 & 3.875 .000 & 298 \\
\hline Konut & 535,5 & 1,00 & 15,00 & $8.032,5$ & 1.300 .000 & 162 & 5.175 .000 & 644 & 3.875 .000 & 298 \\
\hline Konut & 535,5 & 1,00 & 15,00 & $8.032,5$ & 1.300 .000 & 162 & 5.175 .000 & 644 & 3.875 .000 & 298 \\
\hline Konut & 535,5 & 1,00 & 15,00 & $8.032,5$ & 1.300 .000 & 162 & 5.175 .000 & 644 & 3.875 .000 & 298 \\
\hline Konut & 535,5 & 1,00 & 15,00 & $8.032,5$ & 1.300 .000 & 162 & 5.175 .000 & 644 & 3.875 .000 & 298 \\
\hline \multicolumn{11}{|l|}{ Konut+ } \\
\hline Ticaret & 750 & 1,00 & 10,00 & 7.500 & 1.700 .000 & 227 & 7.878 .000 & 1.050 & 6.178 .000 & 363 \\
\hline Konut & 535,5 & $\mathrm{I}, 00$ & 15,00 & $8.032,5$ & 1.300 .000 & 162 & 5.175 .000 & 644 & 3.875 .000 & 298 \\
\hline Konut & 535,5 & 1,00 & 15,00 & $8.032,5$ & 1.300 .000 & 162 & 5.175 .000 & 644 & 3.875 .000 & 298 \\
\hline
\end{tabular}

görülmektedir. 2019 yılı inşaat alanı $\mathrm{m}^{2}$ birim fıyatları ise 644 TL ve 1050 TL olarak belirlenmiştir. MI örnek alanı taşınmazlarının değer değişiminin 2012 ve 2019 yılları arasında ortalama \%316,57 oranında artış gösterdiği görülmektedir. Açık bir şekilde gözlenen bu reel değer artışının yanında, enflasyon karşısında \%244, Avro karşısında \%73 ve HKFE karşısında \%।88 oranında taşınmazların getiri elde ettikleri hesaplanmıştır (Şekil II). Bu oranlar değerlendirildiğinde, enflasyonist şartlar altında dahi MI alanındaki taşınmazların alım-satım değerlerinde oldukça yüksek artış oranları yaşandığı görülmektedir. Bu de- ğer artışında, alanın son yıllarda yaşadığı hızlı kentleşmenin ve yüksek inşaat alanları sağlayan imar şartlarının da etkisi vardır.

\subsection{M2 Örnek Alanı}

M2 örnek alanı, Yenidoğan mahallesinde Kayseri kent merkezinin güneydoğusunda yaklaşık $6 \mathrm{~km}$ mesafede yer almaktadır. Bölgedeki yapılar daha çok son 10-15 yılda inşa edilmiş 6-12 arasında değişen kat adedine sahip, zemin katları ticaret üst katları konut kullanımında olan yapılardır (Şekil 12). Alanın 


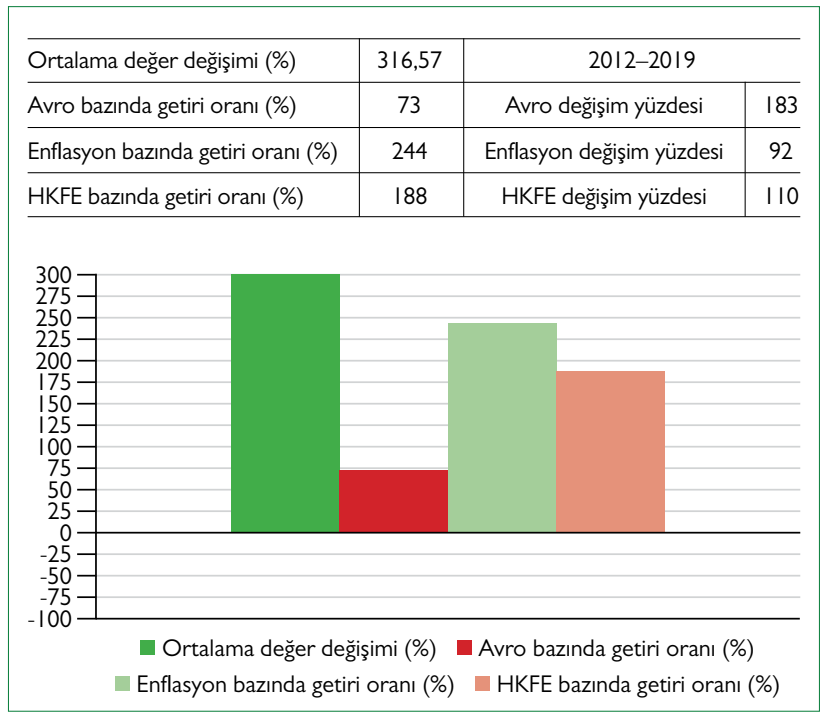

Şekil I I. MI örnek alanında taşınmazların 2012-2019 değer değişimleri.

çevresinde Talas Kaymakamlığı, Talas Belediyesi ve Talas Lisesi bulunmaktadır. Kolay ulaşılabilen alanda son dönemde kentsel dönüşüm faaliyetleri de hız kazanmıştır.

M2 örnek alanında güncel değerlemesi yapılabilir durumda, imar ve kullanım niteliği değişmemiş 12 adet parsel belirlenmiş ve emsal karşılaştırma yöntemi ile 2019 yılı güncel birim değerleri tespit edilmiştir. Alanda bulunan altı parselin imar kullanımı konut+ticaret, diğerleri konuttur. 8 parsel için emsal üzerinden uygulama yapıldığı için TAKS belirtilmemiş, diğerlerinin TAKS'ları ise 0.30 ve 1.00 olarak belirlenmiştir. Alandaki parsellerde KAKS’lar ise I.8 ile 2.45 arasında değişmekte, sadece bir parselde 10 emsal verildiği görülmektedir (Tablo 5).

2012 yılında hazırlanan değerleme raporlarında örnek alandaki parsellerde inşaat alanı $\mathrm{m}^{2}$ birim fiyatlarının 25I TL ile 674 TL arasında olduğu görülmektedir. 2019 yılı değerleme çalış- masında ise bu değerler 755 ve 1940 TL arasında değişmektedir. 2012 ve 2019 yılları arasında taşınmazların değerlerindeki reel artışın ise ortalama \%।87,42 olduğu tespit edilmiştir. Aynı dönemde enflasyon karşısında elde edilen getiri \% I04, Avro karşısında elde edilen getiri \%2, HKFE karşısında elde edilen getiri ise \%70 olarak hesaplanmıştır (Şekil 13). Bu getiri oranları M2 alanındaki taşınmazların değerlerinde ölçü alınan yatırım enstrümanları karşısında dayanıklı oranlarda artış olduğunu göstermektedir.

\subsection{M3 Örnek Alanı}

Talas'ın son yıllarda kentleşen diğer bir kesimi olan Bahçelievler mahallesinde yer alan M3 örnek alanı, Kayseri kent merkezinin güneydoğusunda ve yaklaşık $6 \mathrm{~km}$ mesafede konumlanmıştır. Alanda apartmanlar genelde 8-12 arasında kat adedine sahip, zemin katta ticaret ve üst katları konut kullanımına sahiptir (Şekil 14). Örnek alanın yakın çevresinde özel bir kolej ve Talas'ın son zamanlarda en popüler ve büyük yeşil alanlarından olan Yamaç Paraşütü İniş Alanı bulunmaktadır.

M3 örneklem alanında güncel değerlemesi yapılabilir durumda, imar ve kullanım niteliği değişmemiş 10 adet parsel tespit edilmiş ve emsal karşılaştırma yöntemi ışığında değerlemeye tabi tutulmuştur. Alandaki parsellerin parsellerin üçünün imar işlevinin konut, diğerlerinin konut+ticaret olduğu, TAKS/ KAKS'ların sekiz parselde $0.2 / 2$, birer parselde ise $0.15 / 3.6$ ve I.0/I0 olduğu, görülmüştür (Tablo 6).

2012 yılında değerleme raporlarında M3 örnek alanındaki taşınmazlarda inşaat alanı $\mathrm{m}^{2}$ birim fiyatlarının $506 \mathrm{TL}$ ile 243। TL arasında, 2019 yılında ise çalışma kapsamında yapılan değerlendirmede II86 TL ile 1855 TL arasında olduğu tespit edilmiştir. Taşınmazların 2012 ve 2019 yılları arasında gösterdiği reel değer artışının ortalama \%।27.8 olduğu görülmek-
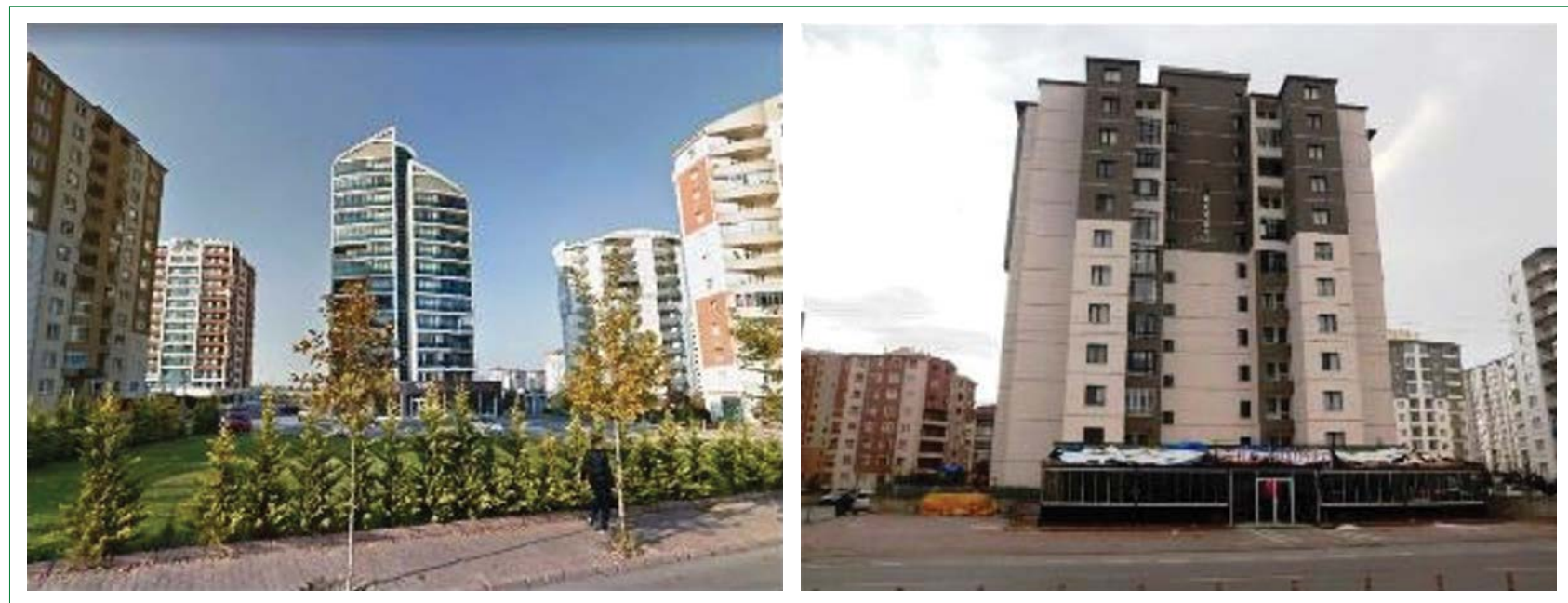

Şekil I2. M2 örnek alanından görüntüler. 
Tablo 5. M2 örnek alanı değerleme tablosu

\begin{tabular}{|c|c|c|c|c|c|c|c|c|c|c|}
\hline İşlev & $\begin{array}{l}\text { Yüzölçüm } \\
\left(\mathrm{m}^{2}\right)\end{array}$ & TAKS & KAKS & $\begin{array}{l}\text { İnşaat alanı } \\
\left(m^{2}\right)\end{array}$ & $\begin{array}{c}2012 \text { değeri } \\
\text { (TL) }\end{array}$ & $\begin{array}{l}2012 \text { birim } \\
\text { fiyatı }\left(\mathrm{TL} / \mathrm{m}^{2}\right)\end{array}$ & $\begin{array}{l}2019 \text { değeri } \\
\text { (TL) }\end{array}$ & $\begin{array}{l}2019 \text { birim } \\
\text { fiyatı (TL) }\end{array}$ & $\begin{array}{l}\text { Fiyat farkı } \\
\text { (TL) }\end{array}$ & $\begin{array}{c}\text { Fiyat farkı } \\
\text { (\%) }\end{array}$ \\
\hline \multicolumn{11}{|l|}{ Konut+ } \\
\hline Ticaret & 6.042 & 0,30 & $\mathrm{I}, 80$ & $10.875,6$ & 7.000 .000 & 644 & 21.103 .000 & 1940 & 14.103 .000 & 201 \\
\hline \multicolumn{11}{|l|}{ Konut+ } \\
\hline Ticaret & 3.710 & - & $\mathrm{I}, 80$ & 6.678 & 4.500 .000 & 674 & 11.500 .000 & 1722 & 7.000 .000 & 155 \\
\hline \multicolumn{11}{|l|}{ Konut+ } \\
\hline Ticaret & 2.412 & - & 1,80 & $4.34 I, 6$ & 2.450 .000 & 564 & 6.268 .000 & 1444 & 3.818 .000 & 156 \\
\hline Konut & 484 & 1,00 & 10 & 4.840 & 1.650 .000 & 341 & 5.405 .000 & 1117 & 3.755 .000 & 228 \\
\hline \multicolumn{11}{|l|}{ Konut+ } \\
\hline Ticaret & 5.583 & - & 1,80 & $10.049,4$ & 4.100 .000 & 408 & 12.650 .000 & 1259 & 8.550 .000 & 209 \\
\hline Konut & 1.088 & - & 2,45 & $2.665,6$ & 670.000 & 251 & 2.013 .000 & 755 & 1.343 .000 & 201 \\
\hline \multicolumn{11}{|l|}{ Konut+ } \\
\hline Ticaret & 5.289 & 0,30 & $\mathrm{I}, 80$ & $9.520,2$ & 3.600 .000 & 378 & 11.098 .000 & 1166 & 7.498 .000 & 208 \\
\hline Konut & 7.048 & - & 2,10 & $14.800,8$ & 5.750 .000 & 388 & 15.985 .000 & 1080 & 10.235 .000 & 178 \\
\hline \multicolumn{11}{|l|}{ Konut+ } \\
\hline Ticaret & 2.310 & $0 ., 30$ & 1,80 & 4.158 & 1.900 .000 & 457 & 5.348 .000 & 1286 & 3.448 .000 & 181 \\
\hline Konut & 5.698 & - & 2,10 & $11.965,8$ & 3.800 .000 & 318 & 11.385 .000 & 951 & 7.585 .000 & 199 \\
\hline Konut & 7.048 & - & 2,10 & $14.800,8$ & 5.650 .000 & 382 & 15.985 .000 & 1080 & 10.335 .000 & 183 \\
\hline Konut & 1.659 & - & 2,45 & $4.064,55$ & 1.660 .000 & 408 & 4.140 .000 & 1019 & 2.480 .000 & 150 \\
\hline
\end{tabular}

\begin{tabular}{|c|c|c|c|}
\hline Ortalama değer değişimi (\%) & 187,42 & \multicolumn{2}{|l|}{$2012-2019$} \\
\hline Avro bazında getiri oranı (\%) & 2 & Avro değişim yüzdesi & 183 \\
\hline Enflasyon bazında getiri oranı (\%) & 104 & Enflasyon değişim yüzdesi & 92 \\
\hline HKFE bazında getiri oranı (\%) & 70 & HKFE değişim yüzdesi & 110 \\
\hline
\end{tabular}

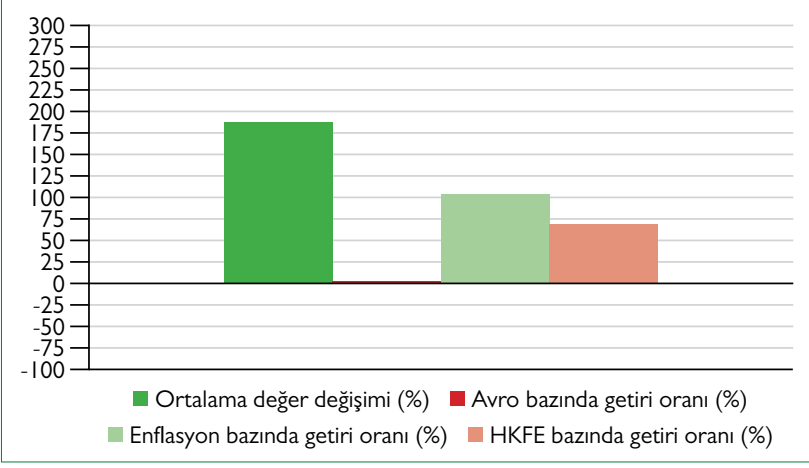

Şekil 13. M2 örnek alanında taşınmazların 2012-2019 değer değişimleri.

tedir. Alandaki taşınmazlar enflasyon karşısında \%39, HKFE karşısında \%।6 getiri elde ederken, Avro karşısında \%30 oranında değer kaybı göstermişlerdir (Şekil 15). Bu oranlara göre alandaki taşınmazların enflasyonist şartlarda, enflasyonu bir miktar aşar oranda artış göstermesine rağmen alım-satım değerlerinde diğer yatırım enstrümanları karşısında dayanıksız oranlarda artış gösterdiği görülmektedir.

\section{Bulgular}

Çalışma kapsamında, koruma alanı içinden ve dışından üçer örnek alan seçilerek, 2012 ve 2019 yılları arasında imar durumu ve fonksiyonu değişmemiş parseller üzerinden değerleme karşılaştırması yapılmıştır. Bu özelliklere uygun olan, koruma alanı içinde KI'de 12 adet, K2'de 10 adet, K3'de ise I I adet olmak üzere toplam 33 adet; koruma alanı dışında MI'de 14 adet, M2'de 12 adet, M3'de ise 10 adet olmak üzere toplam 36 adet parsel değerleme işlemine tabi tutulmuştur. İşlem sonucunda ulaşılan değer artışları ilgili tablolarda sunulmuştur.

Yapılan değerleme işlemi sonunda elde edilen değer artışlarına ilişkin veride anlamlılık analizi yapılmıştır. Bir sonraki aşamada ise 2012 ve 2019 yılı arasındaki değer değişimlerinin öncelikle taşınmazların sit içinde ve sit dışında olması ile olan ilişkisi sorgulanmıştır. Bu amaçla yapılan korelasyon analizinde 2012 ve 2019 yılları arasında hem TL bazında hem de artış oranı yüzdesindeki değişim ile sit alanı içinde ve dışında olma arasında kuvvetli bir ilişki olduğu görülmüştür (Pearson Correlation değeri sırası ile TL bazında 0,659 ve yüzdelik artış bazında 0,705) (Tablo 7 ve Tablo 8).

Çalışmada değerlemeye işleminde veri seti için ayrıca faktör analizi yapılmıştır. Bu analiz sonucunda, tabloyu oluşturan ve- 

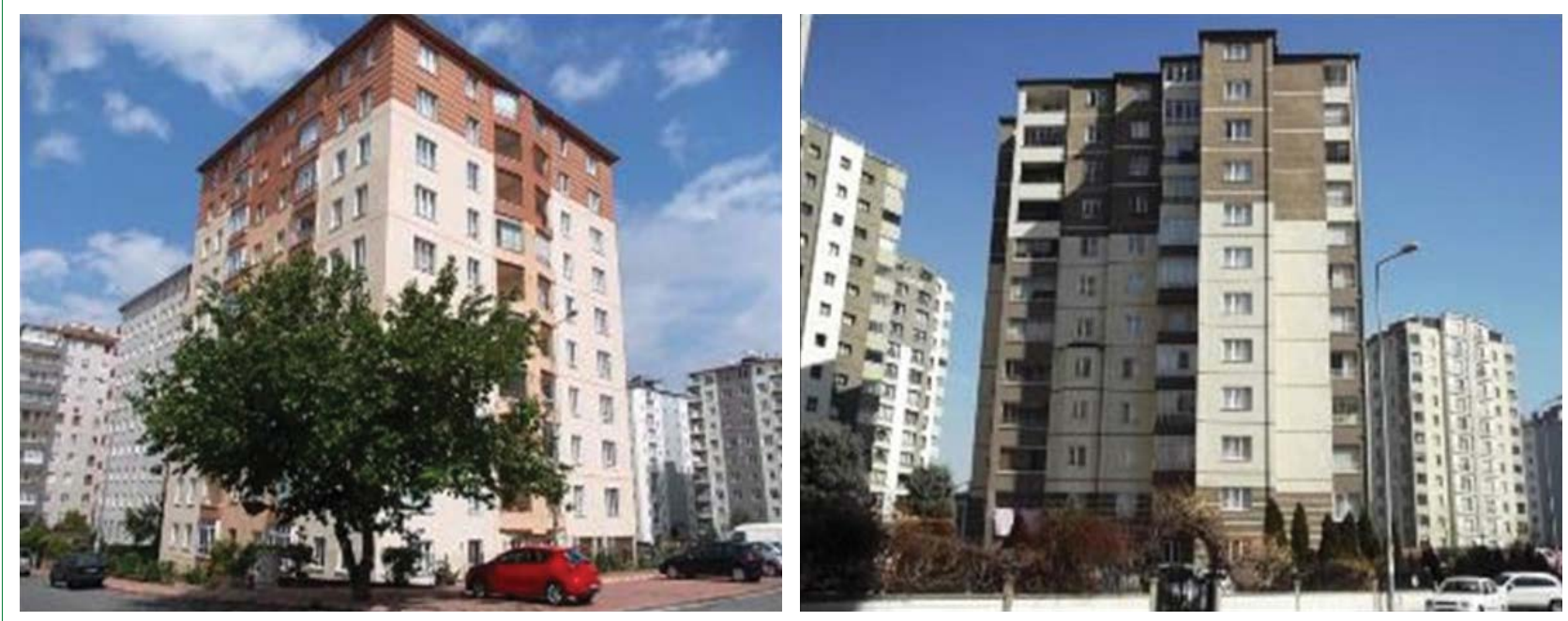

Şekil I4. M3 örnek alanından görüntüler.

Tablo 6. M3 örnek alanı değerleme tablosu

\begin{tabular}{|c|c|c|c|c|c|c|c|c|c|c|}
\hline İşlev & $\begin{array}{c}\text { Yüzölçüm } \\
\left(m^{2}\right)\end{array}$ & TAKS & KAKS & $\begin{array}{l}\text { İnşaat alanı } \\
\left(m^{2}\right)\end{array}$ & $\begin{array}{l}2012 \text { değeri } \\
\text { (TL) }\end{array}$ & $\begin{array}{l}2012 \text { birim } \\
\text { fiyatı }\left(\mathrm{TL} / \mathrm{m}^{2}\right)\end{array}$ & $\begin{array}{l}2019 \text { değeri } \\
\text { (TL) }\end{array}$ & $\begin{array}{l}2019 \text { birim } \\
\text { fiyatı (TL) }\end{array}$ & $\begin{array}{l}\text { Fiyat farkı } \\
\text { (TL) }\end{array}$ & $\begin{array}{l}\text { Fiyat farkı } \\
\text { (\%) }\end{array}$ \\
\hline Konut & 8.890 & 0,20 & 2,00 & 17.780 & 9.000 .000 & 506 & 21.275 .000 & 1.197 & 12.275 .000 & 137 \\
\hline \multicolumn{11}{|l|}{ Konut+ } \\
\hline Ticaret & 8.181 & 0,15 & 3,60 & $29.451,6$ & 21.900 .000 & 744 & 54.625 .000 & 1.855 & 32.725 .000 & 149 \\
\hline \multicolumn{11}{|l|}{ Konut+ } \\
\hline Ticaret & 4.711 & 0,20 & 2,00 & 9.422 & 8.000 .000 & 849 & 16.675 .000 & 1.770 & 8.675 .000 & 108 \\
\hline \multicolumn{11}{|l|}{ Konut+ } \\
\hline Ticaret & 4.773 & 0,20 & 2,00 & 9.546 & 8.000 .000 & 838 & 16.675 .000 & 1.747 & 8.675 .000 & 108 \\
\hline \multicolumn{11}{|l|}{ Konut+ } \\
\hline Ticaret & 8.582 & 0,20 & 2,00 & 17.164 & 14.500 .000 & 845 & 31.625 .000 & 1.843 & 17.125 .000 & 118 \\
\hline Konut & 574 & 1,00 & 10,00 & 5.740 & 4.000 .000 & 697 & 9.200 .000 & 1.603 & 5.200 .000 & 130 \\
\hline \multicolumn{11}{|l|}{ Konut+ } \\
\hline Ticaret & 4.756 & 0,20 & 2,00 & 9.512 & 7.300 .000 & 767 & 16.675 .000 & 1.753 & 9.375 .000 & 129 \\
\hline \multicolumn{11}{|l|}{ Konut+ } \\
\hline Ticaret & 4.515 & 0,20 & 2,00 & 9.030 & 7.000 .000 & 775 & 15.525 .000 & 1.719 & 8.525 .000 & 122 \\
\hline \multicolumn{11}{|l|}{ Konut+ } \\
\hline Ticaret & 4.745 & 0,20 & 2,00 & 9.490 & 7.000 .000 & 738 & 17.825 .000 & 1.878 & 10.825 .000 & 154 \\
\hline Konut & 1.280 & 0,15 & 3,60 & 4.608 & 2.450 .000 & 532 & 5.463 .000 & 1.186 & 3.013 .000 & 123 \\
\hline
\end{tabular}

rilerin iki grup faktör ile değer artışlarını yansıttı̆̆ı görülmüştür. Sit alanı içinde olup olmama, 2012-2019 yılları arasında TL bazında fiyat değişimi ve değer artışının yüzdesi birinci grup faktörü oluştururken; değer artışının yüzdesi ve sit alanında olup olmama ikinci grup faktörü oluşturmuştur. Bu iki faktör bir arada, değer değişimine ilişkin varyansın \%96,458'ini oluşturmuştur. Bu oran, elde edilen değerlerin sit alanı içinde olup olmama koşuluna bağlı olarak gösterdikleri farklılığın anlamlı olduğunu göstermiştir (Tablo 9).
Faktör analizinin bu şekilde sonuç vermesi olağan görülmektedir. Çünkü emsal karşılaştırma yöntemi ile değerleme işleminde, piyasa koşullarında standart bir hesaplama yöntemi kullanılmaktadır. Bu hesaplamada sit içindeki ve dışındaki taşınmazlara yönelik değerleme işleminde piyasa koşullarına göre yapılan hesaplama 2012 ve 2019 yılları için aynı yöntemlerle yapıldığı için tutarlı sonuçlar vermiştir. Bir başka ifadeyle, 20।2-2019 yılları arasında yaşanan TL bazındaki değer artışı ile bu artışın yüzdelik oranı ile gerçekleştirilen faktör anali- 


\begin{tabular}{|c|c|c|c|}
\hline \multirow{2}{*}{$\begin{array}{l}\text { Ortalama değer değişimi (\%) } \\
\text { Avro bazında getiri oranı (\%) }\end{array}$} & \multirow{2}{*}{$\begin{array}{c}127,8 \\
-30\end{array}$} & \multicolumn{2}{|l|}{$2012-2019$} \\
\hline & & Avro değişim yüzdesi & 183 \\
\hline Enflasyon bazında getiri oranı (\%) & 39 & Enflasyon değişim yüzdesi & 92 \\
\hline HKFE bazında getiri oranı (\%) & 16 & HKFE değişim yüzdesi & 110 \\
\hline
\end{tabular}

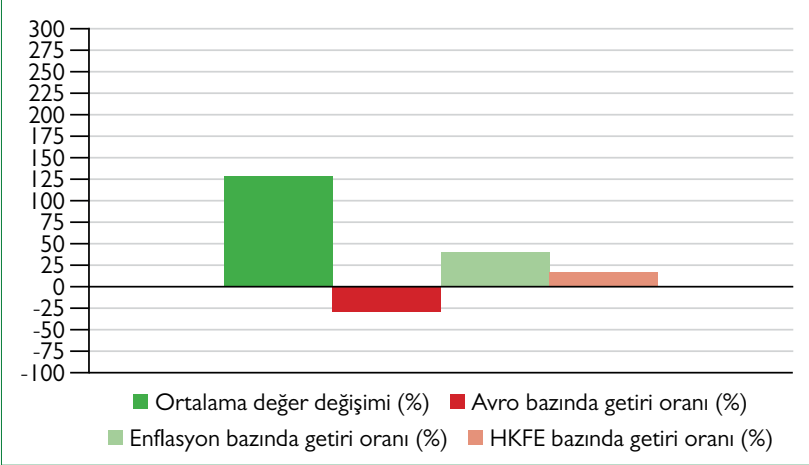

Şekil I5. M3 örnek alanında taşınmazların 2012-2019 değer değişimleri.

zi, doğrudan profesyonel değerleme uygulamasındaki tespit edilen bedellerle şekillendiğinden, faktör analizi profesyonel değerlemede kullanılan emsal karşılaştırma yöntemi kriterlerini istatistiksel açıdan doğrulamıştır. Bu açıdan, sit alanında bulunmanın ve piyasa koşullarında belirlenen bedelde başlıca etken olan rant beklentisinin düşük olmasının önemli bir faktör olduğunu söylemek mümkündür.

Çalışmada elde edilen veri seti son olarak regresyon analizine tabi tutulmuştur. Çalışmada değerlemeye tabi tutulan örnek alanlarda ortaya çıkan değer artışının (bağımsız değişken), sit alanı içinde olma ya da olmama durumuna (kategorik bağımlı değişken) göre değiştiği yönünde bir model kurulmuştur. Veri setine ilişkin belirtilmesi gereken diğer önemli husus değer artışının TL olarak karşılığını kullanarak analiz yapmanın sağlıklı yorum yapılmasını önleyeceği endişesidir. Çünkü değer artışına ilişkin rakamlar parselin büyüklüğüne göre birbirlerine göre çeşitlilik sunmaktadır. Bu açıdan her taşınmazın elde ettiği fiyat artışının yüzdelik oranını ifade eden değişken regresyon analizine dahil edilmiştir. Bağımlı değişkenin kategorik veri niteliğinde olmasından ötürü “lojistik regresyon analizi”, bu bağımlı değişken iki seçenek (sit alanında olma / sit alanının dışında olma) içerdiği için ise "binary lojistik regresyon analizi" kullanılmıştır.

$\mathrm{Bu}$ analiz sonucuna göre, "sit alanında olup olmama koşulunun fiyat artış miktarını etkilediği” şeklinde kurulan modelin, değerleme işleminde 2012 ve 2019 yılları arasında elde edilen fiyat artış yüzdelerindeki artışın,

-sit alanı içindeki taşınmazlar için \%90,9'unu

-sit alanı dışındaki taşınmazlar için \%86, I'ini

-taşınmazların tümü için ise \%88,4'ünü

doğruladığı tespit edilmiştir. Yine aynı analizde, fiyatlardaki artış yüzdelerine ilişkin anlamlılık oranı sig: 0,00 I olarak bulun-
Tablo 7. 2012-2019 arasında TL bazında değer değişimi ve sit durumu korelasyonu

\begin{tabular}{llcc}
\hline & \multicolumn{2}{c}{ Correlations } & \\
\cline { 2 - 3 } & & Sit & Fiyat farkı (TL) \\
\hline \multirow{2}{*}{ Sit } & Pearson Correlation & 1 & $0,659 * *$ \\
& Sig. (2-tailed) & & 0,000 \\
& $\mathrm{~N}$ & 69 & 69 \\
Fiyat farkı (TL) & Pearson Correlation & $0,659 * *$ & 1 \\
& Sig. (2-tailed) & 0,000 & \\
& $\mathrm{~N}$ & 69 & 69 \\
\hline
\end{tabular}

**: Correlation is significant at the 0.01 level (2-tailed).

Tablo 8. 2012-2019 arasında değer değişimi yüzdesi ve sit durumu korelasyonu

\begin{tabular}{llcc}
\hline & \multicolumn{2}{c}{ Correlations } & \\
\cline { 2 - 3 } & \multicolumn{2}{c}{ Sit } & Fiyat farkı (TL) \\
\hline \multirow{2}{*}{ Sit } & Pearson Correlation & 1 & $0,705^{* *}$ \\
& Sig. (2-tailed) & & 0,000 \\
& $\mathrm{~N}$ & 69 & 69 \\
Fiyat farkı (TL) & Pearson Correlation & $0,705^{* *}$ & $\mathrm{I}$ \\
& Sig. (2-tailed) & 0,000 & \\
& $\mathrm{~N}$ & 69 & 69 \\
\hline
\end{tabular}

**: Correlation is significant at the 0.01 level (2-tailed).

muş ve bu oran 0,005 'ten küçük olmasından ötürü regresyon analizi için kurulan modeli doğrulamıştır (Tablo 10).

İstatistiki açıdan anlamlılı̆̆ı sınanan altı örnek alan için yapılan değerleme çalışmalarının sonucunda kentsel sit alanında bulunan parsellerin, yapılaşma ve doku koşullarının farklıı̆̆ı bir önem arz etmeksizin enflasyon ve avro karşısında değer kaybına uğradığı ortaya çıkmıştır. Kentsel alandan daha izole konumda yer alan $\mathrm{KI}$ ve $\mathrm{K} 2$ alanlarında benzer nitelikte değer kaybı yaşanmaktayken, kentsel alan ile daha iç içe olan K3 alanında görülen değer kaybı, KI ve K2'ye nazaran, oldukça yüksek olarak bulunmuştur. Bu alanın komşusu niteliğindeki $\mathrm{MI}$ alanı ise tam tersi bir özellik göstererek hem enflasyon hem de avro karşısında oldukça kârlı bir konumda yer almaktadır.

Örnek alınan taşınmazların birim fiyatları sıralandığında 2012 yılında en yüksek değere sahip ilk 15 taşınmaz içinde, sit alanındaki 14 adet parsel yer almaktayken; 2019 yılında bu sayının I I'ye gerilediği görülmüştür. Bu sıralamada 2012 yılında en düşük değere sahip I 5 taşınmaz içinde, sit alanından hiçbir parsel bulunmazken; 2019 yılında sit alanından 5 parselin en düşük değere sahip I 5 parsel içine dahil olduğu tespit edilmiştir (Tablo II). Bu durum, Talas kentsel sit alanındaki taşınmaz değerlerinin, yakın zamana kadar hep yüksek düzeyde seyretmekte 
Tablo 9. Faktör analizi

\section{Component Matrix}

\section{Component}

I 2

\begin{tabular}{lll}
\hline Sit & 0,798 & 0,512 \\
2012 değeri (TL) & 0,922 & $-0,380$ \\
2019 değeri (TL) & 0,964 & $-0,258$ \\
Fiyat farkı (TL) & 0,977 & $-0,170$ \\
Fiyat farkı (\%) & 0,401 & 0,889 \\
\hline
\end{tabular}

Extraction method: principal component analysis. a: 2 components extracted.

Total variance explained

\begin{tabular}{|c|c|c|c|c|c|c|c|c|c|}
\hline \multirow[b]{2}{*}{ Comp. } & \multicolumn{3}{|c|}{ Initial eigenvalues } & \multicolumn{3}{|c|}{ Extraction sums of squared loadings } & \multicolumn{3}{|c|}{ Rotation sums of squared loadings } \\
\hline & Total & $\%$ of variance & Cumulative \% & Total & $\%$ of variance & Cumulative \% & Total & $\%$ of variance & Cumulative \% \\
\hline I & 3,531 & 70,616 & 70,616 & 3,531 & 70,616 & 70,616 & 3,127 & 62,538 & 62,538 \\
\hline 2 & 1,292 & 25,842 & 96,458 & $\mathrm{I}, 292$ & 25,842 & 96,458 & 1,696 & 33,921 & 96,458 \\
\hline 3 & 0,165 & 3,302 & 99,761 & & & & & & \\
\hline 4 & 0,012 & 0,239 & 100,000 & & & & & & \\
\hline 5 & $-2,15 \mid \mathrm{E}-16$ & $-4,302 \mathrm{E}-15$ & 100,000 & & & & & & \\
\hline
\end{tabular}

Extraction method: Principal component analysis.

Tablo I0. Binary lojistik regresyon analizi

\section{Classification table ${ }^{\mathrm{a}}$}

\section{Predicted}

Sit

\begin{tabular}{llcccc} 
& Observed & & Sit içi & Sit dışı & $\begin{array}{c}\text { Percentage } \\
\text { correct }\end{array}$ \\
\hline Step I & Sit & Sit içi & 30 & 3 & 90,9 \\
& & Sit dışı & 5 & 31 & 86,1 \\
& & & & & 88,4 \\
\hline
\end{tabular}

a: The cut value is 0.500 .

Variables in the equation

\begin{tabular}{llccccrr}
\hline & & B & S.E. & Wald & df & Sig. & Exp(B) \\
\hline \multirow{2}{*}{ Step I I $^{\mathrm{a}}$} & Fiyat farkı (\%) & 0,120 & 0,037 & 10,363 & 1 & 0,001 & 1,127 \\
& Constant & $-14,821$ & 4,431 & 11,188 & 1 & 0,001 & 0,000 \\
\hline
\end{tabular}

a: Variable(s) entered on step I: Fiyat farkı (\%).

olduğunu, ancak 7 yıllık zaman diliminde bu alanların değerlerinde kayıp olmamakla birlikte yarattıkları rant ve yatırım enstrümanları açısından, yeni kentleşen alanlara nazaran açık bir şekilde kayıplar yaşadığını göstermektedir. Uzun vadede bu du- rum sit alanının çekiciliğini yitireceğine dair önemli bir işarettir. $\mathrm{Bu}$ tablodaki bir diğer sonuç ise $\mathrm{MI}$ bölgesinde yer alan konut+ticaret işlevli arsaların tamamının en düşük değere sahip son I5'ten yükselmiş olmasıdır. Bu durum, ticaret kullanı- 
Tablo II. Yıllara göre birim fiyat değer sıralaması

\begin{tabular}{|c|c|c|c|c|c|}
\hline Sira & $\begin{array}{c}2012 \\
\text { birim } \\
\text { fiyat }\end{array}$ & $\begin{array}{c}2019 \\
\text { birim } \\
\text { fiyat }\end{array}$ & Sira & $\begin{array}{l}2012 \\
\text { birim } \\
\text { fiyat }\end{array}$ & $\begin{array}{c}2019 \\
\text { birim } \\
\text { fiyat }\end{array}$ \\
\hline I & 3.263 & 5.663 & 35 & 532 & I.197 \\
\hline 2 & 1.643 & 3.396 & 36 & 506 & 1.186 \\
\hline 3 & 1.574 & 3.148 & 37 & 496 & 1.166 \\
\hline 4 & $1.51 \mathrm{I}$ & 2.963 & 38 & 465 & I. 147 \\
\hline 5 & 1.440 & 2.876 & 39 & 457 & 1.117 \\
\hline 6 & 1.432 & 2.847 & 40 & 456 & 1.080 \\
\hline 7 & I.I75 & 2.171 & 41 & 452 & 1.080 \\
\hline 8 & 1.105 & 2.103 & 42 & 408 & I.07I \\
\hline 9 & 1.069 & 2.090 & 43 & 408 & 1.050 \\
\hline 10 & 1.037 & 1.951 & 44 & 402 & 1.050 \\
\hline II & 1.003 & 1.940 & 45 & 388 & 1.050 \\
\hline 12 & 968 & 1.916 & 46 & 382 & 1.050 \\
\hline 13 & 898 & 1.878 & 47 & 378 & 1.019 \\
\hline 14 & 883 & 1.855 & 48 & 373 & 979 \\
\hline 15 & 849 & 1.843 & 49 & 355 & 951 \\
\hline 16 & 845 & 1.806 & 50 & 347 & 938 \\
\hline 17 & 838 & 1.770 & 51 & 341 & 913 \\
\hline 18 & 789 & 1.770 & 52 & 318 & 911 \\
\hline 19 & 779 & 1.753 & 53 & 307 & 775 \\
\hline 20 & 775 & 1.747 & 54 & 278 & 755 \\
\hline 21 & 767 & 1.722 & 55 & 251 & 755 \\
\hline 22 & 744 & 1.719 & 56 & 227 & 747 \\
\hline 23 & 738 & 1.650 & 57 & 227 & 712 \\
\hline 24 & 723 & 1.628 & 58 & 227 & 674 \\
\hline 25 & 697 & 1.622 & 59 & 227 & 644 \\
\hline 26 & 674 & 1.603 & 60 & 162 & 644 \\
\hline 27 & 667 & 1.511 & 61 & 162 & 644 \\
\hline 28 & 649 & 1.468 & 62 & 162 & 644 \\
\hline 29 & 644 & 1.444 & 63 & 162 & 644 \\
\hline 30 & 617 & I.307 & 64 & 162 & 644 \\
\hline 31 & 616 & 1.286 & 65 & 162 & 644 \\
\hline 32 & 600 & 1.283 & 66 & 162 & 644 \\
\hline 33 & 564 & 1.259 & 67 & 162 & 644 \\
\hline \multirow[t]{2}{*}{34} & 542 & I. 222 & 68 & 162 & 644 \\
\hline & & & 69 & 162 & 556 \\
\hline
\end{tabular}

mının alandaki kentleşme ve değer artışında ivmelendirici rolü olduğunu göstermektedir.

Aynı yerleşme ve aynı bölgenin farklı mevkilerinde olup sadece koruma alanı içinde ve dışında kalmalarına göre değerleri, değer artış oranları ve getiri oranları farklılaşan parsellerin birim değerlerindeki değişimi açıklayan ana faktör koruma kararları olmaktadır. Özellikle birbirine komşu haldeki MI bölgesi ile K3 bölgesi arasındaki getiri oranı grafiklerinde gözlemlenen farklılığın açıklanmasında parsel mesafelerinin oldukça yakın ve sit alanında bulunma dışında, konuma dayalı tüm unsurların oldukça benzer olduğuna dikkat çekmek gerekir.

2019 yılı değerlemesinde sit alanı sınırları dışında yer alan parsellerin tamamının ortalama değer artışı enflasyon oranlarının üzerinde seyretmektedir. Ancak bu veriye sit alanı sınırları içinde yer alan parseller üzerinden bakıldığında incelenen parsellerin tamamının ortalama değer artışının enflasyon oranlarının altında olduğu ortaya çıkmaktadır. Avro değeri değişim yüzdesi ile ortalama değer değişimleri kıyaslandığında ise koruma statüsünün parsellerin avro karşısında ortalama getiri oranını ciddi miktarda düşürdüğü görülmektedir. Avro karşısındaki değer, sit dışındaki taşınmazlarda ise açık bir artış göstermektedir.

Çalışmada karşıılıklı analiz bağlamında ele alınan son veri ise TR72 Kayseri-Sivas-Yozgat Hedonik Konut Fiyat Endeksi (HKFE) değişim yüzdesi olmuştur. Merkez Bankası verilerine göre 2012 ve 2019 yılları arasında HKFE değişim oranı söz konusu endeksin değişim oranı +\% I I0'dur. HKFE bazında sit dışındaki örnek alanların hepsi, MI en yüksek olmak üzere, artı yönde getiri değeri gösterirken sit alanındaki üç örnek alan da negatif değer göstermiştir.

\section{Sonuç}

Bu makale kapsamında, emsal değerleme yöntemi ile yapılan değerleme işleminde çevredeki emlak danışmanlarının görüşleri, çevredeki emsal satışlar, araştırmada verileri kullanılan özel firmanın değer haritalarından faydalanılarak bölgedeki satışta olan konut fonksiyonlu taşınmazların fiyatları belirlenmiş ve birim satış değerleri tespit edilmiştir. İkinci olarak, maliyet yöntemi uygulanarak inşaat maliyetleri düşülmüş, her bir dairenin arsa payı değeri bulunmuş ve böylece arsa birim değerlerine ulaşılmıştır. Çalışmada bu klasik yöntemlerin kullanılmasının nedeni halen SPK mevzuatına bağlı olarak, değerleme firmaları tarafindan bankalara hazırlanan raporlarda da aynı yöntemlerin kullanılıyor olmasıdır.

Değerleme işleminde bir taşınmazın değerinde etkili olan birçok faktör söz konusudur ve bundan ötürü bu unsurların değişkenliğinin ve taşınmazın değerinde ne kadar etkili olduğunun saptanması taşınmaza değer belirlemede çok önemli hale gelmektedir. Ancak Ülkemizdeki mevzuatta bu faktörlerin neler olduğu ve ağırlıkları net olarak tanımlanmamaktadır. Yapılan çeşitli akademik çalışmalar ışığında belirli oranlar oldukça sübjektif ve piyasa kabulleri içerisinde kullanılmaktadır.

Değerlemeye etki eden faktörler konusunda ilk olarak Yomralıoğlu (1993), ardından Nişancı (2005) çalışma yapmış, sonrasında ise Çakır ve Sesli (2013) toplam 32 faktör içeren bir değerlendirme yapmışlardır. Bu değerlendirme sonucunda; izin verilen kat adedi, imar planındaki durum (tamamının kamusal 
ya da konut dışında bir kullanıma sahip olması), parselin kullanım alanı, konumun gözde bir mahalde olup olmaması, varolan cazibe merkezine yakınlık, imar adası içindeki konum, çevre, kamusal hizmetlerin varlığı, bulunulan yerin sosyo-kültürel yapısı, kullanılabilir alan, şehir merkezine uzaklık, caddeye çıkış, manzara ve cephe faktörleri değerlemede sırasıyla etkin olan faktörler olarak tespit edilmiş, diğer faktörlerin değerlemeye etkilerinin olmadığı gözlenmiştir (Çakır ve Sesli, 20I3).

Ülkemizde yapılan değerleme uygulamalarında korunma ve tescil statülerinin bir faktör olarak ele alınmadığı görülmektedir. Akademik literatürde yapılan incelemede bu konuda henüz kapsamlı çalışmaların yer almadığı anlaşılabilmektedir. Değerleme sektöründe de bu konunun dikkate alınmadığı gözlenmektedir. Bu çalışmaya veri sağlayan firma yetkilileri ile yapılan görüşmede sektörde faal olan çok sayıda bankanın değerleme konusundaki yönergelerinde tarihi eser olmanın ya da sit alanında bulunmanın risk getirici faktörler olarak ele alındığı ifade edilmektedir. Çalışma kapsamında elde edilen değer değişimlerine ilişkin sonuçlarda da koruma statülü alanda yer almanın piyasa koşullarında dezavantajlı bir durum olduğu görülmüştür.

Yapılan değerlemeler sonucunda hem sit alanında hem de sit dışı alanlarda TL bazlı reel fiyatlarda kesin artışın olduğu görülmüştür. Ancak sit dışı alanlarda bu reel artış, enflasyon oranı, Avro kuru ve HKFE açısından ele alındığında net ve yüksek oranda kârlılığı, dolayısıyla rant artışını ifade ederken; sit alanı içinde enflasyon oranı, Avro kuru ve HKFE açısından açık bir zararı ifade etmektedir.

Talas'ın, Kayseri metropolünün büyüme ve genişleme etkisi altında, son 20 yılda geçirdiği hızlı ve yoğun kentleşme süreci doğrultusunda, MI, M2 ve M3 örnek alanlarındaki bu hızlı rant artışının kaynakları anlaşılabilmektedir. Ancak sit alanı açısından konu ele alındığında; Kayseri merkezi ile aynı etki alanı içinde olmasına ve M rumuzlu alanlarla uzak mesafede olmamasına rağmen sit alanındaki taşınmazlarda kapitalizasyon düzeyinin negatife döndüğü ortaya çıkmaktadır. Bu durum, kentsel sit alanının Talas yerleşmesinin geçirdiği hızlı kentleşme sürecinden yararlanamadığını ve daha uzun vadede terk edilme riski ile karşı karşıya kalacağını göstermektedir.

Yapılan çalışma açık bir şekilde göstermiştir ki; sit alanındaki arsalar serbest piyasa koşullarında alım-satım olanakları açısından düşüş göstermekte, enflasyonist şartlar altında değer artışları yaşamalarına karşın kıyas gayrimenkuller ile yatırım enstrümanlarına oranla değer kaybetmekte ve hâlihazırda ülkemizde uygulanmakta olan politikalar da bu durumu iyiye götürmemektedir. Niceliksel araştırmaların sonuçları ile diğer ekonomik faktörlerin değişimlerinin getiri oranları kıyaslandığında koruma kararlarının taşınmazların piyasa değerleri üzerinde ülkemiz şartlarında olumsuz bir sonuç doğurduğu bu sonuçlarla ortaya çıkmaktadır.
Diğer ülke örnekleri üzerinde yapılmış çalışmalar incelendiğinde, hemen hemen her çalışmada, tescillenerek miras statüsü kazanmış olmanın koruma alanındaki taşınmazlar üzerinde hep değer artışı yaratıcı bir faktör olduğu açıkça vurgulanmaktadır. Bu durumun, söz konusu ülkelerde kültürel ve toplumsal açıdan koruma bilincinin oluşmuş olmasının ve tüm aktörlerce korumaya karşı olumlu bir tavrın varlığının bir sonucu olduğu açıktır. Talas örneğinde tespit edilmiş olan değer kayıpları göz önüne alındığında, gerçekçi koruma politikalarının hayata geçirilmesinde, Ülkemizde var olduğu gözlenen korumaya karşı negatif algının tersine çevrilmesi ve koruma bilincinin kurumsal ve toplumsal düzeyde benimsetilmesi ve güçlendirilmesi gerekmektedir. Aksi taktirde, etkili ve etkin koruma için vazgeçilemez unsurlar olan ekonomik aktörlerin koruma alanlarında faaliyet gösterme olanakları kalmayacaktır. 


\section{KAYNAKLAR}

Aliefendioğlu, Y. (2011). Türkiye’de Koruma Alanlarındaki Taşınmazların Kullanımı ve Koruma Statülerinin Taşınmaz Piyasaları ve Değerlerine Etkileri: Muğla İli Örneği (Doktora tezi). Ankara Üniversitesi/Fen Bilimleri Enstitüsü, Ankara.

Alkay, E. (2002). Hedonik Fiyat Yöntemi ile Kentsel Yeşil Alanların Ekonomik Değerlerinin Ölçülmesi (Doktora Tezi). İ.T.Ü./Fen Bilimleri Enstitüsü, İstanbul

Asabere, P. K., Huffman, F. E., Mehdian, S. (1994). The Adverse Impacts of Local Historic Designation: The Case of Small Apartment Buildings in Philadelphia. The Journal of Real Estate Finance and Economics, 8, 225-234.

Ashworth, G. J. (2002). Conservation Designation and the Revaluation of Property: The Risk of Heritage Innovation. International Journal of Heritage Studies, 8 (1), 9-23

Çakır, P., Sesli, F. A. (2013). Arsa Vasıflı Taşınmazların Değerine Etki Eden Faktörlerin ve Bu Faktörlerin Önem Sıralarının Belirlenmesi. Harita Teknolojileri Elektronik Dergisi, 5 (3), 1-16.

Cebula, R. J. (2009). The Hedonic Pricing Model Applied to the Housing Market of the City of Savannah and Its Savannah Historic Landmark District. The Review of Regional Studies, 39, 9-22.

Eichengreen, B. (1997). Economics and Culture in the Writing of Financial History. Washington, DC: Departments of Economics and Political Science University of California, Berkeley Research Department International Monetary Fund

Erdem, N. (2016). Türkiye İçin Bir Taşınmaz Değerleme Sistemi Yaklaşımı (Yüksek Lisans Tezi). Erciyes Üniversitesi/Fen Bilimleri Enstitüsü. Kayseri.

Heintzelman, M. D., Altieri, J. A. (2013). Historic Preservation: Preserving Value? The Journal of Real Estate Finance and Economics, 46, 543-563.

Klamer, A., Zuidhof, P.W. (1998). The Role of the Third Sphere in the World of the Arts, XX Conference of the Association of Cultural Economics International, Barcelona.

Lazrak, F., Nijkamp, P., Rietveld, P., Rouwendal, J. (2014). The Market Value of Cultural Heritage in Urban Areas: An Application of Spatial Hedonic Pricing. Journal of Geographical Systems, 16, 89-114.

Leichenko, R. M., Coulson, N. E., Listokin, D. (2001). Historic Preservation and Residential Property Values: An Analysis of Texas Cities. Urban Studies, 38 (11), 1973-1987

Licciardi, G., Amirtahmasebi, R. (Ed.). (2012). The Economics of Uniqueness - Investing in Historic City Cores and Cultural Heritage Assets for Sustainable Development. Washington, DC: The World Bank.

Lichfield, N. (1988). Economics in Urban Conservation, Cambridge: Cambridge University Press

Lichfield, N. (1997). Cultural Built Heritage in Community Impact Evaluation, London: UCL Press

Nas, B. B. (2011). YSA ve DVM Yöntemleri ile Taşınmaz Değerlemesi İçin Bir Yaklaşım Geliştirme. (Yüksek Lisans Tezi). Selçuk Üniversitesi/Fen Bilimleri Enstitüsü, Konya

Nişancı, N. (2005). Coğrafi Bilgi Sistemi ile Nominal Değerleme Yöntemine Dayalı Piksel Tabanlı Kentsel Taşınmaz Değer Haritalarının Üretilmesi. (Doktora Tezi). K.T.Ü./Fen Bilimleri Enstitüsü, Trabzon

Noonan, D. S. (2013). Market Effects of Historic Preservation. I. Rizzo, A. Mignosa (Ed.), Handbook on the Economics of Cultural Heritage içinde (s. 344-363). Cheltenham: Edward Elgar Publishing.

Noonan, D. S., Krupka, D. J. (2011). Making - or picking - Winners: Evidence of Internal and External Price Effects in Historic Preservation Policies. Real Estate Economics, 39, 379-407.

Noonan, D.S., Krupka D. J. (2008). Determinants of Historic and Cultural Landmark Designation: Why We Preserve What We Preserve, Bonn: Georgia Institute of Technology, IZA Discussion Paper No. 3777
Nuhoğlu, B. A. (2007). Gayrimenkul Değerleme. (Yüksek Lisans Tezi). Ondokuz Mayıs Üniversitesi/Fen Bilimleri Enstitüsü, Samsun.

Ost, C. (2010). Heritage in Historic Cities: Economic and Strategic Analysis, Damascus: UNESCO Euromed Heritage Strengthening of Institutional, and Legal Framework, Ministry of Culture Syria, Euromed, Workshop.

Ökten, A. E. (2012) Tarihi Konut Yapılarını ve Alanlarını Korumanın Ekonomik Etkilerinin Değerlendirilmesi-Galata Örneği. (Doktora Tezi). İ.T.Ü./Fen Bilimleri Enstitüsü, İstanbul

Özer, M. (2010). Taşınmaz Değerlemesinde Kullanılan Finansal ve Sayısal Yöntemler: Topsis ve Yeni Çoklu Kriter Modelleriyle Bir Uygulama. (Yüksek Lisans Tezi). Dokuz Eylül Üniversitesi/Sosyal Bilimler Enstitüsü, İzmir.

Tanrıvermiş, H. (2016). Gayrimenkul Değerleme Esasları. Ankara: Lisanslama Sınavları Çalışma Kitapları. erişim https://docplayer.biz. tr/15973700-Gayrimenkul-degerleme-esaslari.html

Thompson, E., Rosenbaum, D., Schmitz, B. (2011). Property Values on the Plains: The Impact of Historic Preservation. The Annals of Regional Science, 47, 477-491.

Yalpır, Ş. (2007). Bulanık Mantık Metodolojisi ile Taşınmaz Değerleme Modelinin Geliştirilmesi ve Uygulaması: Konya Örneği. (Doktora Tezi). Selçuk Üniversitesi/Fen Bilimleri Enstitüsü, Konya

Yıldırım, E. (2005). Gayrimenkul Değerleme Esasları. İstanbul: Bilgi Üniversitesi Seminer Notlar1.

Yılmaz, N. (2005). Kent Merkezlerindeki Kentsel Sit Alanlarında Değişim Sürecinin Değerlendirilmesi. (Yüksek Lisans Tezi). İ.T.Ü./Fen Bilimleri Enstitüsü, İstanbul.

Yomralığlu, T. (1993). The Investigation of a Value-Based Urban Land Readjustment Model and Its Implementation Using Geographical Information Systems. (Doktora Tezi). University of Newcastle Upon Tyne, Newcastle.

Yomralığlu, T. (1997). Taşınmaz Değerlendirilmesi ve Kat Mülkiyeti Mevzuatı. JEFOD-Kentsel Alan Düzenlemelerinde İmar Planı Uygulama Teknikleri, 153-169. erişim https://web.itu.edu.tr/tahsin/Arsiv/tahsin/ Yayn_MakaleTR_files/74_05.pdf 